\title{
On the Observations and Environmental Modeling in Xingó Hydropower Plant - São Francisco Basin, Brazil: Present and Future Hydroclimatic Features
}

Wanderson Luiz-Silva ( $\nabla$ wanderweather@gmail.com )

Electrical Energy Research Center (CEPEL) https://orcid.org/0000-0001-8589-7301

Maria Elvira Piñeiro Maceira

University of the State of Rio de Janeiro (UERJ)

Otto Corrêa Rotunno-Filho

Federal University of Rio de Janeiro (UFRJ)

Sin Chan Chou

National Institute for Space Research (INPE)

\section{Research Article}

Keywords: climate change, climate model, hydropower, precipitation, São Francisco, streamflow

Posted Date: March 24th, 2021

DOl: https://doi.org/10.21203/rs.3.rs-204568/v1

License: (c) (i) This work is licensed under a Creative Commons Attribution 4.0 International License.

Read Full License 
On the Observations and Environmental Modeling in Xingó Hydropower Plant - São Francisco Basin, Brazil: Present and Future Hydroclimatic Features

Climate change in the São Francisco basin

Wanderson Luiz-Silva ${ }^{1,2, *}$ (ORCID 0000-0001-8589-7301)

Maria Elvira Piñeiro Maceira ${ }^{1,3}$ (ORCID 0000-0001-5204-1355)

Otto Corrêa Rotunno-Filho² (ORCID 0000-0003-2763-4401)

Sin Chan $\mathrm{Chou}^{4}$ (ORCID 0000-0002-8973-1808)

${ }^{1}$ Department of Energy Optimization and Environment (DEA), Electrical Energy Research Center (CEPEL), Rio de Janeiro, Brazil

${ }^{2}$ Alberto Luiz Coimbra Institute of Postgraduate Studies and Research in Engineering (COPPE), Federal University of Rio de Janeiro (UFRJ), Rio de Janeiro, Brazil

${ }^{3}$ Institute of Mathematics and Statistics (IME), University of the State of Rio de Janeiro (UERJ), Rio de Janeiro, Brazil

${ }^{4}$ Center for Weather Forecasting and Climate Studies (CPTEC), National Institute for Space Research (INPE), Cachoeira Paulista, Brazil

* Corresponding author

Address: Av. Horácio Macedo, 354, Cidade Universitária, Eletrobras Cepel, Ilha do Fundão, Rio de Janeiro, RJ, Brazil, 21941-911.

Emails: wanderweather@gmail.com; wanderson@cepel.br Telephone: $+55(21) 99929-1448$ 
1 On the Observations and Environmental Modeling in Xingó Hydropower Plant -

2 São Francisco Basin, Brazil: Present and Future Hydroclimatic Features

3

4

5

6

7

\begin{abstract}
The São Francisco river basin plays a critical role in the hydroelectrical operational planning of Brazil. Understanding the hydroclimatic dynamic regime and, consequently, related climate changes is essential for decision-makers of the hydroelectrical sector. In this context, this work takes the Xingó hydropower plant and its drainage area as a reference for climatic and hydrological analyzes. Observed rainfall in the drainage basin and streamflow measurements in the power plant between 1975 and 2016 are used to assess the climatology of the region and to identify trends in the time series. In addition, a methodological framework based on numerical modeling of the hydroclimatic variables is employed to examine the representation of the present climate (1961 to 1990) and to investigate the future projections (2011 to 2100). The SMAP rainfall-runoff model and the Eta regional climate model nested within two global models are adopted in this investigation under the RCP4.5 and RCP8.5 IPCC scenarios. In Xingó, the average annual precipitation is about $978 \mathrm{~mm}$ and the average annual streamflow is $2,534 \mathrm{~m}^{3} \cdot \mathrm{s}^{-1}$. This region is marked by the monsoon cycle, with a clear rainy (October to March) and dry (April to September) period. There is no trend regarding precipitation, while the streamflow time series show a statistically significant decreasing trend in the present climate. Climate projections point to reduction in rainfall and streamflow during the $21^{\text {st }}$ century. The results showed in this work revealed to be crucial to better understand the energy security for Xingó in the present and future climates.
\end{abstract}

Keywords climate change, climate model, hydropower, precipitation, São Francisco, streamflow

Word count (from introduction to declarations): 5,573 
The operation and planning of the Brazilian electricity sector are predominantly based on hydroelectric sources. According to EPE - Energy Research Office (EPE, 2019), about $63.8 \%$ of the installed energy capacity in Brazil comes from hydroelectric power plants (HPPs). Therefore, the hydroelectric projects responsible for transforming streamflow into energy strongly depend on the precipitation behavior in their drainage areas (Collischonn et al., 2007; Lima and Lall, 2010; Luiz-Silva et al., 2019). Thus, it is essential to know the details associated with the hydroclimatic characteristics of the drainage basin, as well as its variability and even possible changes in the long-term.

Brazil's hydroelectric system has several reservoirs that act to regulate streamflow between the rainy and dry periods in each region (Maceira et al., 2002; Bezerra et al., 2010). However, the occurrence of reduced rainfall for long periods, especially during the rainy season, can lead to energy rationing at the local level, in addition to the use of more expensive and polluting energy sources, such as thermoelectric power plants (TPPs).

Through the National Interconnected Electrical System (SIN), Brazil can coordinate the energy transmission between the different regions mainly due to the distinct climatic aspects of each area. Brazil has a prominently tropical climate (Alvares et al., 2013) with more frequent and intense precipitation in the Northern and Southern regions, recurrent droughts in the Northeastern region, in addition to a monsoon regime especially in the Midwestern and Southeastern regions, thus characterizing a rainy season and a dry season (Cavalcanti et al., 2009; Carvalho et al., 2012; Marengo et al., 2012a; Luiz-Silva et al., 2020a).

On the other side, several studies have shown changes in observed temperature and rainfall patterns in some regions of Brazil over the past decades (Liebmann et al., 2004; Haylock et al., 2006; Barros et al., 2008; Sansigolo and Kayano, 2010; Satyamurty et al., 2010; Rao et al., 2016; Zandonadi et al., 2016; Soares et al., 2017; Luiz-Silva et al., 2019; Avila-Diaz et al., 2020; among others). Alterations related to the air temperature directly reflect on the hydrological cycle through evapotranspiration and precipitation. In this sense, the detected trends in precipitation have an immediate effect on the rivers' streamflow regime (Arora and Boer, 2001). 
This work investigates the São Francisco river basin, which is the major river for the electricity supply in the Northeastern region of Brazil. The basin has a long river with several waterfalls. Dams have been built in recent decades to structure the nine HPPs that are currently in operation. However, the climate changes identified and projected for the future can considerably impact on both energy generation and other activities that depend on the region's water resources (Marengo et al., 2012b; Jong et al., 2018; Luiz-Silva et al., 2020b).

In this context, this paper aims to analyze the current precipitation and streamflow features and those expected for the future at the Xingó HPP, which drains most of the São Francisco river basin. The climatology and the observed trends over the past years are evaluated, as well as the simulated scenarios over the next decades in terms of precipitation and streamflow are jointly explored. The study area and procedures employed are described in Section 2. In Section 3, the results related to the characteristics of the hydropower generation examined based on climate observations and modeling and hydrological impacts are shown and discussed. Section 4 presents the concluding remarks.

\section{Methodology}

\subsection{Study Area}

Fig. 1 shows the study area of this work. Xingó HPP is located between the states of Alagoas and Sergipe, in the Northeastern region of Brazil. The Xingó power plant is built in the São Francisco river basin and it has a drainage area of $617,000 \mathrm{~km}^{2}(96 \%$ of the basin) and an installed capacity of 3,162 MW. The power plant position in the river, in addition to power generation, constitutes a reservoir for the development of irrigation and water supply projects in part of Northeastern Brazil.

Fig. 1 Location of the Xingó hydropower plant and its drainage area (in white color)

\subsection{Data}

Monthly precipitation data come from 328 rainfall stations of the ANA - National Water Agency of Brazil, located along the São Francisco river basin from 1975 to 2016. According to ANA (2012), these data are consistent, that is, they are information that has 
undergone a treatment of identification and correction of failures through various methods, such as regional weighting and linear regression. The precipitation data were interpolated in a $25-\mathrm{km}$ grid using the inverse square distance method (ISD; Viola et al., 2010).

The potential evapotranspiration data come from monthly climatological averages from the Brazilian National Institute of Meteorology (INMET) between 1981 and 2010 available for 310 meteorological stations throughout Brazil. Those records were also interpolated by the ISD technique and are used for the calibration of the hydrological model. Monthly streamflow data between 1975 and 2016 were obtained from the Brazilian National Electric System Operator (ONS). Precipitation and streamflow data are analyzed for trends and they serve as input information for rainfall-runoff modeling.

\subsection{Trends Tests}

- Trends Significance

To analyze the statistical significance of present and future trends, the Mann-Kendall nonparametric test (Sneyers, 1990) is used. The null hypothesis considered is the nonexistence of increasing or decreasing trends in the time series. In addition, this method assumes that the succession of values occurs independently, and that the probability distribution remains unchanged, that is, the data does not need to belong to a specific distribution. The significance level $\alpha$ adopted is $5 \%$, which corresponds to a confidence level of $95 \%$.

\section{- Trends Magnitude}

To assess the magnitude of the trends, the Sen's Curvature test (Sen, 1968) is used. It is also a non-parametric technique that assumes a linear trend in the data series. The test is calculated as follows:

$$
S E N=\operatorname{median}\left(\frac{x_{j}-x_{i}}{j-i}\right), \forall j>i,
$$

where $x_{j}$ is the value of the variable in a specific period (for example, a year) and $x_{i}$ is the value of the variable in the previous period. Sen's Curvature test is insensitive to outliers and missing information, thus being more realistic and rigorous than a simple linear regression. 

in climatological series when compared to other parametric methods. Thus, several researchers have been applying these techniques in studies on climate trends in several regions of the globe, including Brazil (Sansigolo and Kayano, 2010; Carvalho et al., 2014; Almeida et al., 2016; Oliveira et al., 2017; Luiz-Silva et al., 2019; among others).

\subsection{Climate Model Dataset}

The present and future precipitation simulations for the Xingó HPP drainage area are based on dynamical downscaling (Pielke and Wilby, 2012) of the Eta regional climate model (Pesquero et al., 2010; Chou et al., 2012; Mesinger et al., 2012) in the HadGEM2ES (Collins et al., 2011; Martin et al., 2011) and MIROC5 (Watanabe et al., 2010) global climate model runs, here forth referred to as Eta-HadGEM2-ES and Eta-MIROC5 models (Chou et al., 2014a; 2014b), respectively. The Eta model comes from the National Institute for Space Research (INPE) in Brazil. The vertical coordinate system $\eta$ used in the Eta model is recommended over South America due to the presence of the steep Andes Mountains (Mesinger, 1984).

The Eta regional model is set up at $20-\mathrm{km}$ resolution, 38 vertical levels in the atmosphere, and model top at $25 \mathrm{hPa}$. Turbulence treatment is based on the MellorYamada level 2.5, in which turbulent kinetic energy is prognosticated (Mellor and Yamada, 1974); the radiative transfer model was developed by the Geophysical Fluid Dynamics Laboratory (GFDL), with the long and short waves parameterized according to Fels and Schwarzkopf (1975) and Lacis and Hansen (1974), respectively. The Eta model uses the Betts-Miller scheme (Betts and Miller, 1986) modified by Janjic (1994) to parameterize convection of shallow and deep clusters; cloud microphysics are parameterized using the Zhao scheme (Zhao and Carr, 1997). The energy transfer processes on the land surface are parameterized by the NOAH scheme (Ek et al., 2003). The Eta-HadGEM2-ES and Eta-MIROC5 model runs are evaluated for the representation of precipitation patterns over the study area, especially the seasonal cycle. Due to the availability of observed data, this evaluation is carried out for the reference period from 1975 to 1990 , taken as the present climate. In this way, the bias correction factor is calculated based on the ratio between the observed and simulated average monthly precipitation according to the Linear-Scaling Approach (Graham et al., 2007; 
Lenderink et al., 2007). These monthly bias correction factors are applied to the future projections of precipitation of the models in the period from 2011 to 2100 , assuming that the bias are invariable in future conditions. Likewise, this correction method is used for air temperature data simulated by the Eta model, which are converted into potential evapotranspiration using the technique of Thornthwaite (1948).

Future projections are based on the Representative Concentration Pathways RCPs (Van Vuuren et al., 2011) scenarios of the Intergovernmental Panel on Climate Change - IPCC Fifth Assessment Report (IPCC, 2013). The four different scenarios are called RCP2.6, RCP4.5, RCP6.0, and RCP8.5 and they correspond to anthropogenic radiative forcing of $2.6 \mathrm{~W} . \mathrm{m}^{-2}, 4.5 \mathrm{~W} . \mathrm{m}^{-2}, 6.0 \mathrm{~W} . \mathrm{m}^{-2}$, and $8.5 \mathrm{~W} . \mathrm{m}^{-2}$, respectively. The scenarios considered in this work are RCP4.5 and RCP8.5. In RCP4.5, the radiative forcing increases almost linearly until about the year 2060, when its elevation rate slows down until it stabilizes at the end of the $21_{\text {st }}$ century. In RCP8.5, the radiative forcing continues increasing beyond 2100. In Brazil, the average increase in the projected air temperature until the end of the $21_{\text {st }}$ century is around $+2.0^{\circ} \mathrm{C}$ for RCP 4.5 and $+4.0^{\circ} \mathrm{C}$ for RCP8.5 based on global climate model runs (IPCC, 2013).

\subsection{Hydrological Simulation}

The observed precipitation and evapotranspiration data are used to calibrate the deterministic hydrological model called Soil Moisture Accounting Procedure (SMAP), developed by Lopes et al. (1982). SMAP is a conceptual rainfall-runoff model (representing physical processes) and lumped (varies only with time).

The SMAP hydrological model represents the storage and water flow through two fictitious linear reservoirs, one in the top layer of the soil (surface reservoir) and the other in the aquifer (groundwater reservoir), as shown in the diagram in Fig. 2. The representative equations of the rainfall-runoff model structure in its monthly version are:

$$
S F=P \cdot\left(\frac{R S O I L}{S A T}\right)^{S U F L}
$$

$$
R E=P E .\left(\frac{R S O I L}{S A T}\right)
$$

$$
R E C=R S O I L \cdot\left(\frac{R S O I L}{S A T}\right)^{4} \cdot R E C O
$$

$$
B F=R U N D E . K U N D E ;
$$


$R_{S O I L} L_{t+1}=R S O I L_{t}+P-S F-R E-R E C ;$

$R U N D E_{t+1}=R U N D E_{t}+R E C-B F ;$

191

$Q=(S F+B F) \cdot \frac{\text { area }}{2630}$.

192

193

194

195

196

197

198

199

200

201

202

203

204

205

206

207

208

209

210

211

212

213

214

215

216

217

218

219

220

Fig. 2 SMAP hydrological model representation with monthly discretization (adapted from Lopes et al. 1982)

In Equation 2, SF is the surface flow, $\mathrm{P}$ is the precipitation, RSOIL is the total water content in the soil reservoir, SAT is the calibrated storage capacity of the soil reservoir, and SUFL is a calibration-defined parameter that converts precipitation into a surface flow. In Equation 3, RE is the real evapotranspiration and PE is the potential evapotranspiration. In Equation 4, REC is the recharge of the underground reservoir and RECO is the recharge coefficient determined by calibration. In Equation 5, BF is the baseline flow, RUNDE is the total water content in the underground reservoir and KUNDE is the depletion rate established by calibration. Equations 6 and 7 calculate the state variables RSOIL and RUNDE at each time step. Finally, Equation 8 represents the final streamflow $Q$ in the drainage basin in question.

Considering that the Xingó HPP drainage area is very large, a translation coefficient was applied to the surface and baseline flow in the rainy (October to March) and dry (April to September) periods. This coefficient is calibrated in such a way as to determine the degree of dependence on the flow of the present month in relation to the previous month. The performance of the hydrological model in simulating the observed streamflow is measured using the Nash-Sutcliffe coefficient - NASH (Nash and Sutcliffe, 1970), given by:

$N A S H=1-\frac{\sum_{t=1}^{N}\left(Q_{o, t}-Q_{s, t}\right)^{2}}{\sum_{t=1}^{N}\left(Q_{o, t}-\overline{Q_{o}}\right)^{2}}$,

where $Q_{o, t}$ is the observed streamflow in the month $t, Q_{s, t}$ is the simulated streamflow in the month $t$ and $\overline{Q_{o}}$ is the average observed streamflow. The closer to $1 \mathrm{NASH}$ it is, the better the simulation performance is.

The calibrated parameters are then used for future projections of streamflow between 2011 and 2100, based on precipitation and evapotranspiration data simulated by the Eta model. In this case, the parameters used are those that obtained the highest NASH. This objective function was pursued through a limited memory algorithm for nonlinear 
optimization (Byrd et al., 1995). Boxplots (Box et al., 2008) and joint plots (Kroonenberg, 1983 ) are used to illustrate some results.

\section{Results}

\subsection{Hydroclimatic Characteristics}

The Xingó HPP drainage area is controlled by two main climate types, one drier and the other more humid (Alvares et al., 2013). In the northern portion of the São Francisco river basin, the semi-arid climate prevails, with the lowest accumulated precipitation in Brazil. In the central-southern sector of the basin, the tropical climate determines the main characteristics of the seasonal variability of total rainfall and streamflow (Fig. 3). Since most of the drainage area is located within the tropical climate, the main feature is the striking difference between a rainy period (October to March) and a dry period (April to September), ranging from average monthly precipitation volumes from about $20 \mathrm{~mm}$ in winter to $180 \mathrm{~mm}$ in summer, and the total of about $978 \mathrm{~mm}$ accumulated in the year.

The South American Monsoon System (SAMS) is the main driver of rainfall in most of the Amazon and central and southeastern Brazil (Gan et al., 2004; Carvalho et al., 2011; Marengo et al., 2012a). The central-southern portion of the São Francisco river basin is subjected to this monsoonal regime. SAMS's main characteristics in Brazil is the formation of a northwest-southeast-oriented cloud band where there are a marked humidity convergence and considerable precipitation volumes (Carvalho et al., 2004). This system, so called the South Atlantic Convergence Zone (SACZ), is primarily responsible for rainfall between October and March in the central-southern sector of the Xingó HPP drainage area. This is the most important period for hydroelectric power generation at Xingó HPP when its streamflow reach the maximum average values around 3,000 to $5,000 \mathrm{~m}^{3} \cdot \mathrm{s}^{-1}$ (Fig. 3).

In contrast, the northern part of the São Francisco river basin has significant effects from the occasional actions of the Upper Tropospheric Cyclonic Vortexes (UTCVs), which are part of the atmospheric dynamics of summer in Brazil (Fedorova et al., 2018). The central region of the UTCV exhibits downward movements that hinder the clouds formation and precipitation. Therefore, it is noted that the main contribution of rainfall to the streamflow of the Xingó HPP comes from the central-southern portion of its drainage area. During autumn and winter, the driest period of the year is established 
in this region (Fig. 3). During this season, the main periodic contributions to low precipitation come from cold fronts. Thus, isolated rainfall totals are recorded in the Xingó HPP drainage basin, but with no relevant contribution to the streamflow.

Fig. 3 Monthly long-term average of precipitation ( $\mathrm{mm}$, blue bars) and streamflow $\left(\mathrm{m}^{3} \cdot \mathrm{s}^{-1}\right.$, green curve) in the Xingó HPP drainage basin for the period from 1975 to 2016

The effect of the precipitation and the size of the drainage area on the streamflow that reaches the Xingó HPP is illustrated in Fig. 4, where the correlation between monthly rainfall and monthly streamflow is plotted considering the verification month (lag0) and the previous month (lag1). The correlation coefficient for lag0 is only 0.475 , while for lag1 this value reaches 0.794 , which shows the strong connection between the precipitation that occurs in one month and the streamflow that will occur in the following month, especially in the rainy season. In addition to the rainfall volumes and the size of the drainage basin, other elements can influence the response time of the streamflow, such as the vegetation interception of the rainfall, the river sinuosity, and the presence of floodplains and supplementary beds flooded in the rainy period.

Fig. 4 Correlation between monthly precipitation $(\mathrm{mm})$ and monthly streamflow $\left(\mathrm{m}^{3} \cdot \mathrm{s}^{-1}\right)$ considering lag0 (rainfall and streamflow of the same month; in blue color) and lag1 (streamflow against rainfall of the previous month; in green color) in the Xingó HPP drainage area for the period from 1975 to 2016 . The correlation (r) and determination $\left(\mathrm{R}^{2}\right)$ coefficients values are shown in the graph

\subsection{Variability and Observed Trends}

The time series of total annual precipitation and average annual streamflow in the study area are shown in Fig. 5. There is marked interannual variability in the data over the analyzed period (1975 to 2016). The Xingó HPP drainage climate is influenced by variations in sea surface temperature (SST) in the Tropical Atlantic and Equatorial Pacific Oceans. In the years of positive (negative) SST anomalies in the Tropical Atlantic Ocean, studies have shown that convection is inhibited (favored) over the drainage basin, which results in total rainfall below (above) the climatology (Bombardi et al., 2014), mainly during the rainy season. The El Niño - South Oscillation (ENSO) phenomenon, in its 
both warm phase (El Niño) and cold phase (La Niña), seems to disturb monsoon precipitation during the summer on a subseasonal scale over eastern Brazil (Grimm, 2003; 2004). The warm phase causes negative anomalies of rainfall during the rainy season, especially over the central-southern portion of the basin.

When assessing the trends over the years, a reduction is detected for both precipitation $\left(-4.3 \mathrm{~mm}\right.$.year $\left.{ }^{-1}\right)$ and streamflow $\left(-41.6 \mathrm{~m}^{3} . \mathrm{s}^{-1}\right.$.year $\left.{ }^{-1}\right)$ in the Xingó HPP drainage basin (Fig. 5). Bezerra et al. (2019) state that there are trends of opposite signs in pluviometric stations separated by a few kilometers away in the São Francisco river basin. The results presented here are the trends after the interpolation of monthly rainfall data for the entire study area, which show a non-significant decrease. However, the decreasing trend of the streamflow was considered statistically significant at the $95 \%$ confidence level. Some works pointed to changes in land cover and use in the São Francisco river basin, in addition to the increasing use of water for crop irrigation (Correia et al., 2006; Maneta et al., 2009; Bezerra et al. 2019).

Fig. 5 Total annual rainfall ( $\mathrm{mm}$; in blue) and average annual streamflow $\left(\mathrm{m}^{3} \cdot \mathrm{s}^{-1}\right.$; in green) observed in the Xingó HPP drainage basin between 1975 and 2016. The trends significance (p) and magnitude (SEN) values obtained through statistical tests are shown

Seasonal trends (Table 1) show that rainfall volumes are decreasing in a statistically significant way only during the winter in the Xingó HPP drainage basin. However, it is worth mentioning that the trend of $-0.2 \mathrm{~mm}_{\text {.year }}{ }^{-1}$ is not strong since this is the driest period of the year in the region. Streamflow reduction occurred in all seasons of the year, with statistical significance, especially in summer $\left(-64.4 \mathrm{~m}^{3} \cdot \mathrm{s}^{-1}\right.$.year $\left.{ }^{-1}\right)$, when the highest streamflow are usually registered due to more frequent and intense precipitation rates.

Table 1 Trends of the total precipitation and the average streamflow in each season of the year in the Xingó HPP drainage area in the period from 1975 to 2016. The values in bold are statistically significant at the $95 \%$ confidence based on the Mann-Kendall test

\subsection{Calibration of the Hydrological Model}


The SMAP model was calibrated in such a way that its parameters found optimal values that could represent the main hydrological characteristics of Xingó HPP. It is worth emphasizing the importance of considering the influence of the streamflow of the previous month on the streamflow of the month in question since there is a travel time through the basin. According to the calibration, it was found that about $83 \%$ of the monthly surface flow between October and March affects the streamflow of the following month. This stage of analysis of the hydrological model is essential not only for the parameter's calibration but also for the investigation of the model performance on the study area in the present climate before its use for future scenarios.

Fig. 6 shows the boxplots and the joint plots for the streamflow observed by ONS and streamflow simulated by the SMAP hydrological model at Xingó HPP. The boxplots in Fig. 6 show that the seasonal variability of the streamflow was well represented by the SMAP model, despite some specific deviations, with a Nash-Sutcliffe coefficient of 0.847. The periods of floods and low streamflow were captured by the model, highlighting the ability to estimate precise parameters for both the rainy and dry periods. The joint plots in Fig. 6 also highlight through the histograms the satisfactory simulation of the frequency distribution of the streamflow. There is a high correlation coefficient (0.92), indicating once again the good performance of the hydrological model in the transition from high to low streamflow, in addition to interannual variability. The parameters here calibrated are used later for the simulation of future projections.

Fig. 6 Boxplots (left) and joint plots (right) of observed streamflow (ONS) and simulated streamflow $\left(\mathrm{m}^{3} \cdot \mathrm{s}^{-1}\right)$ from the SMAP hydrological model for the Xingó HPP for the period from 1975 to 2016

\subsection{Evaluation of the Climate Model}

Precipitation and air temperature derived from the Eta-HadGEM2-ES and Eta-MIROC5 regional climate model simulations are properly evaluated in the present climate before being used in the future climate. According to Randall et al. (2007), the confidence in a model is based on a careful evaluation of the spatio-temporal representation of the variables, in which the simulated results are compared with observations. The observed 
and simulated monthly average rainfall and air temperature in the Xingó HPP drainage are shown in Fig. 7.

It is noted that the total precipitation is underestimated by the Eta-HadGEM2-ES model for the basin, although between May and August, during the direst period, the precipitation values are well represented (Fig. 7). The Eta-MIROC5 model simulations tend to overestimate rainfall volumes between February and August and underestimate between October and January. The variability of the Eta-HadGEM2-ES model is less marked compared to the Eta-MIROC5 model, and both seem to delay the peak of the rainy season by 1 to 2 months, which usually occurs between November and January according to the observed data.

The Eta regional climate model was run using the Betts-Miller-Janjic (Janjic, 1994) cumulus convection parameterization scheme. Previous works have shown that this scheme underestimates heavy rains (Chou et al., 2012; Calado et al., 2017), although tend to correctly position the rainy areas. The positive trend observed in the extremely heavy precipitation in the São Francisco river basin is reproduced by both Eta-HadGEM2-ES and Eta-MIROC5 (Dereczynski et al., 2020). On the other hand, both climate model runs underestimate the air temperature, but its typical seasonal cycle of small amplitude in a tropical region is relatively well simulated. Both errors in precipitation and air temperature require further investigation as pointed by Chou et al. (2014a).

Fig. 7 Monthly long-term average of total precipitation ( $\mathrm{mm}$; left) and air temperature $\left({ }^{\circ} \mathrm{C}\right.$; right) observed and simulated by the Eta-HadGEM2-ES and Eta-MIROC5 climate model runs in the Xingó HPP drainage basin between 1975 and 1990

To eliminate systematic deviations in precipitation and air temperature in the study area, a linear monthly bias correction factor is employed considering the ratio between the observed and simulated variables, thus allowing the data to reflect a variability more consistent with observations (Teutschbein and Seibert, 2012). After removing the deviations, this corrected model output is used in the simulations of the streamflow that reaches the Xingó HPP. As it is a climate change model, here we do not seek a fit to the yearly values, but rather a good simulation of its seasonal cycle, thus reproducing the onset and the demise of the rainy period and, consequently, capturing the high and low values of the streamflow. Fig. 8 shows the streamflow simulations at Xingó 
HPP through the corrected data of the Eta-HadGEM2-ES and Eta-MIROC5 model runs, using the parameters previously calibrated by the SMAP model. It appears that the magnitude of the streamflow can be well captured, and the results with the data from the Eta-HadGEM2-ES model still slightly underestimate the streamflow in the rainy months, while the Eta-MIROC5 model shows average values closer to the observations.

Fig. 8 Streamflow $\left(\mathrm{m}^{3} \cdot \mathrm{s}^{-1}\right)$ simulated by SMAP hydrological model driven by the EtaHadGEM2-ES (left) and the Eta-MIROC5 (right) climate model data after bias correction at Xingó HPP between 1975 and 1990

\subsection{Future Projections of Precipitation and Streamflow}

Fig. 9 shows the present and future climate scenarios of the annual accumulated precipitation considering the RCP4.5 and RCP8.5 IPCC scenarios output by the EtaHadGEM2-ES and Eta-MIROC5 climate model runs. Future precipitation projections point to a decrease in the Xingó HPP drainage area, and the RCP8.5 scenario of the EtaHadGEM2-ES model shows the greatest reduction. The simulations indicate an average reduction of around $-20 \%$ to $-30 \%$ in annual total rainfall during the $21_{\text {st }}$ century in comparison with the present climate. In quantitative terms, considering the worst case scenario, the average annual rainfall may be reduced from 1,000 $\mathrm{mm}$ to around $800 \mathrm{~mm}$, but with occasional extreme drought events. Marengo et al. (2012b) and Chou et al. (2014b) state that projections of intensification of the South Atlantic Subtropical Anticyclone (SASA) would increase atmospheric pressure over eastern Brazil, thus causing frequent blockages or decelerations of cold fronts that advance from high to low latitudes. So, weather systems producing precipitation would reach less frequently the São Francisco river basin.

Fig. 9 Boxplots of annual rainfall volumes ( $\mathrm{mm}$ ) simulated in the present climate (1961 to 1990) and the future climate (2011 to 2100) by the Eta-HadGEM2-ES and Eta-MIROC5 regional climate model runs after the application of the monthly linear factor of bias correction considering the RCP4.5 and RCP8.5 IPCC scenarios in the Xingó HPP drainage area

The present and future climates of mean seasonal streamflow in the Xingó HPP are exhibited in the boxplots in Fig. 10, considering the RCP4.5 and RCP8.5 scenarios in 
the Eta-HadGEM2-ES and Eta-MIROC5 climate model runs. As expected, due to the reduction in the precipitation volumes over the drainage basin, a decrease in the streamflow that reach the Xingó HPP is projected throughout the $21_{\text {st }}$ century. This decrease in streamflow is more evident in the period of the highest values of surface flow (austral summer and autumn) when the average reduction in some periods can be around $-30 \%$ to $-40 \%$ in relation to the historical average. During the austral summer, the present climate shows a higher frequency of average streamflow about 4,000 to $5,000 \mathrm{~m}^{3} . \mathrm{s}^{-1}$, while in the future climate this higher occurrence could be established in values around 2,000 to $3,000 \mathrm{~m}^{3} \cdot \mathrm{s}^{-1}$.

The reduction in streamflow is also a reflection of the increase in air temperature and, consequently, in evapotranspiration. Souza and Oyama (2011) and Marengo and Bernasconi (2015) show that expanded aridity, combined with land degradation, can enhance the risk of desertification in various parts of the Northeastern Brazil, including some sectors of the São Francisco river basin. The impact of desertification on streamflow should directly impact the hydroelectric generation. The energy production would be extremely vulnerable not only to the rainfall amount, but also to the marked changes in its variability.

Fig. 10 Relative and cumulative distribution functions of mean seasonal streamflow $\left(\mathrm{m}^{3} \cdot \mathrm{s}^{-1}\right)$ observed in the present climate (1961 to 1990 , in green color) and simulated by the SMAP hydrological model using data from the Eta-HadGEM2-ES and Eta-MIROC5 climate model runs in the future climate (2011 to 2100 , in orange color), after monthly bias correction, considering the RCP4.5 and RCP8.5 IPCC scenarios at Xingó HPP

Table 2 shows the projected precipitation and streamflow trends for the Xingó HPP during the $21_{\text {st }}$ century, according to the RCP4.5 and RCP8.5 scenarios of the EtaHadGEM2-ES and Eta-MIROC5 climate model runs. Note that the magnitudes of decrease are statistically significant for all scenarios, except for RCP4.5 of the EtaHadGEM2-ES model. As previously observed as more pessimistic, the RCP8.5 scenario of the Eta-HadGEM2-ES model shows the strongest reduction rates, about -2.1 mm.year1 for the precipitation and $-12.2 \mathrm{~m}^{3} \cdot \mathrm{s}^{-1} \cdot \mathrm{year}^{-1}$ for the streamflow. The streamflow diminution also happens in its extreme values, both for the years of floods and for the years of drought. Fig. 11 shows the percentage of years in which the average annual 
streamflow at Xingó HPP should be below the $10_{\text {th }}$ percentile of the historical average (1961 to 1990) and above the $90_{\text {th }}$ percentile, in the period from 2011 to 2100 . It is verified that, except for the RCP4.5 scenario of the Eta-MIROC5 model, about $40 \%$ of annual streamflow by 2100 are expected to be very low. Regarding the years of floods, only about $5 \%$ of the average streamflow are expected to register very high values. These scenarios are somewhat in line with the projections of an increase in the frequency of consecutive dry days for the Northeastern Brazil identified by Marengo et al. (2017) and which further reinforce the climatological risk of desertification of this area, as pointed out by Spinoni et al. (2015).

Table 2 Projections of precipitation and streamflow trends over the $21_{\text {st }}$ century (2011 to 2100 ) according to RCP4.5 and RCP8.5 scenarios of the Eta-HadGEM2-ES (EH2) and Eta-MIROC5 (EM5) regional climate model runs at the Xingó HPP. The values in bold were considered statistically significant at the $95 \%$ confidence level by the Mann-Kendall test

Fig. 11 Projections of the average annual streamflow percentage (STREAMfut) between 2011 and 2100 below the $10_{\text {th }}$ percentile (STREAMp10hist) of the historical period (1991 to 1990) and above the $90^{\text {th }}$ percentile (STREAMp90hist), according to the RCP4.5 and RCP8.5 scenarios of the Eta-HadGEM2-ES (EH2) and Eta-MIROC5 (EM5) models at Xingó HPP

\section{Conclusions}

Current and projected climate changes for the coming decades can significantly impact the hydrological cycle in the São Francisco river basin, in the Northeast Brazil. Therefore, this work focused on examining the drainage area of an important hydroelectric power

472 plant in the region as a reference for the present and future characteristics of precipitation and streamflow. Based on observed data and hydroclimate modeling, present and future scenarios were discussed for the study area. This work highlights the importance of similar analysis for other economic sectors, in addition to electricity generation in Brazil, as water supply, agriculture, navigation, industries, among others.

The hydroclimatic characterization reinforced the seasonal dependence between hydroelectric energy production in the Xingó HPP drainage basin and the annual cycle of precipitation, marking a rainy season between October and March and a dry season between April and September. The SIN is based on these properties so that the energy 
demand in Brazil is met without interruption through the energy transmission between the different regions of the territory. Because the São Francisco river basin is highly exposed to recurrent droughts, mainly in its central-northern portion, it is essential to be aware of the trends that have been observed over the past decades. The decreasing rates in streamflow must be examined in such a way that correct measures of management of water resources can reduce the vulnerability of the basin.

Before investigating the future climate, this work thoroughly assessed the performance of the climate and hydrological models in the present climate in the Xingó HPP drainage area. The satisfactory representation of the seasonal precipitation cycle, corrected by a monthly linear factor, and the streamflow express a greater degree of reliability in the model information, even if this does not guarantee the occurrence as shown in the future projections. When analyzing future hydroclimatic circumstances, it is evident from all available scenarios that the same direction of trends is found, that is, a reduction in rainfall and streamflow in the Xingó HPP. In a context of sustainability, HPPs act as renewable source that contributes to mitigate the emission of greenhouse gases into the environment, but on the other hand, it may suffer from the impacts of global climate change (Berga, 2016).

These and other scenarios must be carefully taken into account since several uncertainties are part of the numerical simulations and the adopted policies. However, at least in qualitative terms of the trends and considering ranges of projections, preliminary conclusions can be structured in order to support new studies of adaptation of the electric sector to the climate changes, especially in a region that already suffers frequently with the extreme effects of the climate. Further scientific research will continue to provide the socioeconomic sectors with information that can ratify or rectify the relevance of practical actions in relation to climate change.

\section{Declarations}

\section{Funding}

This research did not receive any specific grant from funding agencies in the public, commercial, or not-for-profit sector.

\section{Competing interests}


513 The authors declare that they have no known competing financial interests or personal

514 relationships that could have appeared to influence the work reported in this paper.

\section{Availability of data}

517 The data come from the National Water Agency of Brazil (ANA), the Brazilian National Institute 518 of Meteorology (INMET), the National Institute for Space Research (INPE) and the National

519 Electric System Operator (ONS). The data were made available upon request.

520

\section{Authors' contributions}

522 Wanderson Luiz-Silva elaborated on the organization and presentation of the results, as well as

523 the bibliographic structuring and the methodology of the work. Maria Elvira Piñeiro Maceira and

524 Otto Corrêa Rotunno-Filho contributed to the management of tasks associated with hydrological 525 modeling, as well as the revision regarding the evaluation of models in the present climate and 526 future projections. Sin Chan Chou is the coordinator responsible for the structure and the runs of 527 the regional climate model used in this work, and also revised the text.

528

\section{Ethics approval}

530 The authors are committed to upholding the integrity of the scientific record.

531

\section{Consent for publication}

533 All individuals listed as authors have agreed to be listed and approved the submitted version of 534 the manuscript.

\section{References}

537

538 Almeida, C.T., Oliveira-Júnior, J.F., Delgado, R.C., Cubo, P., Ramos, M.C. (2016). 539 Spatiotemporal rainfall and temperature trends throughout the Brazilian Legal Amazon, 1973540 2013. International Journal of Climatology, 37(4), 2013-2026.

541 Alvares, C.A., Stape, J.L., Sentelhas, P.C., Gonçalves, J.L.M., Sparovek, G. (2013). Köppen’s 542 climate classification map for Brazil. Meteorologische Zeitschrift, 22(6), 711-728.

543 ANA - National Water Agency of Brazil (2012). Orientações para consistência de dados 544 pluviométricos. Brasília: Ministry of the Environment.

545 Arora, V.K., Boer, G.J. (2001). Effects of simulated climate change in the hydrology of major 546 river basins. Journal of Geophysical Research: Atmospheres, 106(D4), 3335-3348. 
547 Avila-Diaz, A., Benezoli, V., Justino, F., Torres, R., Wilson, A. (2020). Assessing current and 548 future trends of climate extremes across Brazil based on reanalyses and earth system model 549 projections. Climate Dynamics, 55, 1403-1426.

550 Barros, V.R., Doyle, M.E., Camilloni, I.A. (2008). Precipitation trends in southeastern South 551 America: relationship with ENSO phases and with low-level circulation. Theoretical and Applied 552 Climatology, 93, 19-33.

553 Berga, L. (2016). The role of hydropower in climate change mitigation and adaptation: a review. 554 Engineering, 2, 313-318.

555 Betts, A.K., Miller, M.T. (1986). A new convective adjustment scheme. II. Single column tests 556 using GATE wave, BOMEX, ATEX and Arctic air-mass data sets. Quarterly Journal of the Royal 557 Meteorological Society, 112, 693-709.

558 Bezerra, B., Barroso, L.A., Brito, M., Porrua, F. et al. (2010). Measuring the Hydroelectric 559 regularization capacity of the Brazilian hydrothermal system. IEEE Power and Energy Society 560 General Meeting, 2010, 1-7.

561 Bezerra, B.G., Silva, L.L., Silva, C.M.S., Carvalho, G.G. (2019). Changes of precipitation 562 extremes indices in São Francisco River Basin, Brazil from 1947 to 2012. Theoretical and Applied 563 Climatology, 135, 565-576.

564 Bombardi, R.J., Carvalho, L.M.V., Jones, C., Reboita, M.S. (2014). Precipitation over eastern 565 South America and the South Atlantic sea surface temperature during neutral ENSO periods. 566 Climate Dynamics, 42, 1553-1568.

567 Box, G.E.P., Jenkins, G,M., Reinsel, G.C. (2008). Time series analysis: forecasting and control. 568 Oxford: Wiley.

569 Byrd, R.H., Lu, P., Nocedal, J. (1995). A limited memory algorithm for bound constrained 570 optimization. SIAM Journal on Scientific Computing, 16, 1190-1208.

571 Calado, R.N., Dereczynski, C.P., Chou, S.C., Sueiro, G. et al. (2018). Evaluation of Eta model 5$572 \mathrm{~km}$ ensemble simulations of an extreme rainfall event over the Paraíba do Sul river basin during 573 January 2000. Revista Brasileira de Meteorologia, 33(1), 83-96. 
574 Carvalho, J.R.P., Assad, E.D., Oliveira, A.F., Pinto, H.S. (2014). Annual maximum daily rainfall 575 trends in the Midwest, southeast and southern Brazil in the last 71 years. Weather and Climate 576 Extremes, 5-6, 7-15.

577 Carvalho, L.M.V., Jones, C., Liebmann, B. (2004). The South Atlantic Convergence Zone: 578 intensity, form, persistence, and relationships with intraseasonal to interannual activity and 579 extreme rainfall. Journal of Climate, 17(1), 88-108.

580 Carvalho, L.M.V., Silva, A.E., Jones, C., Liebmann, B. et al. (2011). Moisture transport and 581 intraseasonal variability on the South America monsoon system. Climate Dynamics, 36, 18655821880.

583 Carvalho, L.M.V., Jones, C., Posadas, A.N.D., Quiroz, R. et al. (2012). Precipitation 584 characteristics of the South American monsoon system derived from multiple datasets. Journal 585 of Climate, 25(13), 4600-4620.

586 Cavalcanti, I.F.A., Ferreira, N.J., Justi da Silva, M.G.A., Silva-Dias, M.A.F. (2009). Tempo e 587 clima no Brasil. São Paulo: Oficina de Textos Publisher.

588 Chou, S.C., Marengo, J.A., Lyra, A.A., Sueiro, G. et al. (2012). Downscaling of South America 589 present climate driven by 4-member HadCM3 runs. Climate Dynamics, 38, 635-653.

590 Chou, S., Lyra, A., Mourão, C., Dereczynski, C. et al. (2014a). Evaluation of the Eta simulations 591 nested in three global climate models. American Journal of Climate Change, 3, 438-454.

592 Chou, S., Lyra, A., Mourão, C., Dereczynski, C. et al. (2014b). Assessment of climate change 593 over South America under RCP4.5 and 8.5 downscaling scenarios. American Journal of Climate 594 Change, 3, 512-527.

595 Collins, W.J., Bellouin, N., Doutriaux-Boucher, M., Gedney, N. et al. (2011). Development and 596 evaluation of an Earth-System model - HadGEM2. Geoscientific Model Development, 4, 10515971075.

598 Collischonn, W., Tucci, C.E.M., Clarke, R.T., Chou, S.C. et al. (2007). Medium-range reservoir 599 inflow predictions based on quantitative precipitation forecasts. Journal of Hydrology, 344(1-2), $600 \quad 112-122$. 
601 Correia, M.F., Silva-Dias, M.A.F., Aragão, M.R.S. (2006). Soil occupation and atmospheric 602 variations over Sobradinho Lake area. Part one: an observation analysis. Meteorology and 603 Atmospheric Physics, 94(1-4), 103-113.

604 Dereczynski, C.P., Chou, S.C., Lyra, A., Sondermann, M. et al. (2020). Downscaling of climate 605 extremes over South America - part I: model evaluation in the reference climate. Weather and 606 Climate Extremes, 29, 100273.

607 Ek, M.B., Mitchell, K.E., Lin, Y., Rogers, E. et al. (2003). Implementation of NOAH land surface 608 advances in the National Centers for Environmental Prediction Operational mesoscale Eta model. 609 Journal of Geophysical Research: Atmospheres, 108(D22), 8851.

610 EPE - Energy Research Office (2019). Brazilian energy balance year 2018. Brasília: Ministry of 611 Mines and Energy.

612 Fedorova, N., Levit, V., Campos, A.M.V. (2018). Brazilian Northeast jet stream: association with 613 synoptic-scale systems. Meteorological Applications, 25, 261-268.

614 Fels, S.B., Schwarzkopf, M.D. (1975). The simplified exchange approximation: a new method 615 for radiative transfer calculations. Journal of the Atmospheric Sciences, 32, 1475-1488.

616 Gan, M.A., Kousky, V.E., Ropelewsky, C.F. (2004). The South American monsoon circulation and its relationships to rainfall over West-Central Brazil. Journal of Climate, 17(1), 47-66.

618 Graham, L.P., Andréasson, J., Carlsson, B. (2007). Assessing climate change impacts on 619 hydrology from an ensemble of regional climate models, model scales and linking methods - a 620 case study on the Lule River basin. Climatic Change, 81, 293-307.

621 Grimm, A.M. (2003). The El Niño impact on the summer monsoon in Brazil: regional processes 622 versus remote influences. Journal of Climate, 16(2), 263-280.

623 Grimm, A.M. (2004). How do La Niña events disturb the summer monsoon system in Brazil? 624 Climate Dynamics, 22, 123-138.

625 Haylock, M.R., Peterson, T.C., Alves, L.M., Ambrizzi, T. et al. (2006). Trends in total and 626 extreme South American rainfall in 1960-2000 and links with sea surface temperature. Journal of 627 Climate, 19(8), 1490-1512. 
IPCC - Intergovernmental Panel on Climate Change (2013). Climate change 2013: the physical 629 science basis. In: Stocker, T.F., Qin, D., Plattner, G.K., Tignor, M. et al. (eds). Contribution of 630 Working Group I to the Fourth Assessment Report on the IPCC. Cambridge: Cambridge 631 University Press.

632 Janjic, Z.I. (1994). The step-mountain Eta coordinate model: further developments of the 633 convection, viscous sublayer and turbulence closure schemes. Monthly Weather Review, 122, $634927-945$.

635 Jong, P., Tanajura, C.A.S., Sánchez, A.S., Dargaville, R. et al. (2018). Hydroelectric production 636 from Brazil's São Francisco River could cease due to climate change and inter-annual variability. 637 Science of the Total Environment, 634, 1540-1553.

638 Kroonenberg, P.M. (1983). Three-mode principal component analysis. Leiden: DSWO Press.

639 Lacis, A.A., Hansen, J.E. (1974). A parameterization of the absorption of solar radiation in Earth's 640 atmosphere. Journal of the Atmospheric Sciences, 31, 118-133.

641 Lenderink, G., Buishand, A., van Deursen, W. (2007). Estimates of future discharges of the river 642 Rhine using two scenario methodologies: direct versus delta approach. Hydrology and Earth 643 System Sciences, 11(3), 1145-1159.

644 Liebmann, B., Vera, C.S., Carvalho, L.M.V., Camilloni, I.A. et al. (2004). An observed trend in 645 central South America precipitation. Journal of Climate, 17(22), 4357-4367.

646 Lima, C.H.R., Lall, U. (2010). Climate informed long term seasonal forecasts of hydroenergy 647 inflow for the Brazilian hydropower system. Journal of Hydrology, 381(1-2), 65-75.

648 Lopes, J.E.G., Braga, B.P.F., Conejo, J.G.L. (1982). SMAP: a simplified hydrologic model. In: 649 Applied Modeling in Catchment Hydrology. Littleton: Water Resources Publications, 167-176.

650 Luiz-Silva, W., Xavier, L.N.R., Maceira, M.E.P., Rotunno-Filho, O.C. (2019). Climatological 651 and hydrological patterns and verified trends in precipitation and streamflow in the basins of 652 Brazilian hydroelectric plants. Theoretical and Applied Climatology, 137, 353-371.

653 Luiz-Silva, W., Oscar-Júnior, A.C., Cavalcanti, I.F.A., Treistman, F. (2020a). An overview of 654 precipitation climatology in Brazil: space-time variability of frequency and intensity associated 655 with atmospheric systems. Hydrological Sciences Journal, 656 doi.org/10.1080/02626667.2020.1863969. 
657

658

659

660

661

662

663

664

665

666

667

668

669

670

671

672

673

674

675

676

677

678

679

680

681

682

683

684

Luiz-Silva, W., Maceira, M.E.P., Rotunno-Filho, O.C. (2020b). Numerical simulations of precipitation and streamflow in current climate and future projections to drainage areas of Brazilian hydroelectric plants. Climate Research, 79, 219-241.

Maceira, M.E.P., Terry, L.A., Costa, F.S., Damázio, J.M., Melo, A.C.G. (2002). Chain of optimization models for setting the energy dispatch and spot price in the Brazilian system. $14^{\text {th }}$ Power Systems Computation Conference, 43(1), 1-7.

Maneta, M.P., Torres, M., Wallender, W.W., Vosti, S. et al. (2009). Water demand and flow in the São Francisco River Basin (Brazil) with increased irrigation. Agricultural Water Management, 96, 1191-1200.

Marengo, J.A., Liebmann, B., Grimm, A.M., Misra, V. et al. (2012a). Recent developments on the South American monsoon system. International Journal of Climatology, 32(1), 1-21.

Marengo, J.A., Chou, S.C., Kay, G., Alves, L.M. et al. (2012b). Development of regional future climate change scenarios in South America using the Eta CPTEC/HadCM3 climate change projections: climatology and regional analyses for the Amazon, São Francisco and the Paraná River basins. Climate Dynamics, 38, 1829-1848.

Marengo, J.A., Bernasconi, M. (2015). Regional differences in aridity/drought conditions over Northeast Brazil: present state and future projections. Climatic Change, 129, 103-115.

Marengo, J.A., Torres, R.R., Alves, L.M. (2017). Drought in Northeast Brazil - past, present, and future. Theoretical and Applied Climatology, 129, 1189-1200.

Martin, G.M., Bellouin, N., Collins, W.J., Culverwell, I.D. et al. (2011). The Had-GEM2 family of Met Office unified model climate configurations. Geoscientific Model Development, 4, 723757.

Mellor, G.L., Yamada, T. (1974). A hierarchy of turbulence closure models for boundary layers. Journal of the Atmospheric Sciences, 31, 1791-1806.

Mesinger, F. (1984). A blocking technique for representation of mountains in atmospheric models. Rivista de Meteorologia Aeronautica, 44, 195-202.

Mesinger, F., Chou, S.C., Gomes, J.L., Jovic, D. et al. (2012). An upgraded version of the Eta model. Meteorology and Atmospheric Physics, 116, 63-79. 
685 Nash, J.E., Sutcliffe, J.V. (1970). River flow forecasting through conceptual models. I. A 686 discussion of principles. Journal of Hydrology, 10(3), 282-290.

687 Oliveira, P.T., Santos e Silva, C.M., Lima, K.C. (2017). Climatology and trend analysis of 688 extreme precipitation in subregions of Northeast Brazil. Theoretical and Applied Climatology, $689130,77-90$.

690 Pesquero, J.F., Chou, S.C., Nobre, C.A., Marengo, J.A. (2010). Climate downscaling over South 691 America for 1961-1970 using the Eta Model. Theoretical and Applied Climatology, 99, 75-93.

692 Pielke, R.A., Wilby, R.L. (2012). Regional climate downscaling: what's the point? Science News 693 by $A G U, 93(5), 52-53$.

694 Randall, D.A., Wood, R.A., Bony, S., Colman, R. et al. (2007). Climate models and their 695 evaluation. In: Climate change 2007: the physical science basis. Contribution of working group 696 I to the fourth assessment report of the IPCC. Cambridge: Cambridge University Press.

697 Rao, V.B., Franchito, S.H., Santo, C.M.E., Gan, M.A. (2016). An update on the rainfall 698 characteristics of Brazil: seasonal variations and trends in 1979-2011. International Journal of 699 Climatology, 36(1), 291-302.

700 Sansigolo, C.A., Kayano, M.T. (2010). Trends of seasonal maximum and minimum temperatures 701 and precipitation in Southern Brazil for the 1913-2006 period. Theoretical and Applied 702 Climatology, 101, 209-216.

703 Satyamurty, P., Castro, A.A., Tota, J., Gularte, L.E.S., Manzi, A.O. (2010). Rainfall trends in the 704 Brazilian Amazon Basin in the past eight decades. Theoretical and Applied Climatology, 99, 139705148.

706 Sen, P.K. (1968). Estimates of the regression coefficient based on Kendall's tau. Journal of the 707 American Statistical Association, 63, 1379-1389.

708 Sneyers, R. (1990). On the statistical analysis of series of observations. Geneva: World 709 Meteorological Organization.

710 Soares, D.B., Lee, H., Loikith, P.C., Barkhordarian, A., Mechoso, C.R. (2017). Can significant 711 trends be detected in surface air temperature and precipitation over South America in recent 712 decades? International Journal of Climatology, 37(3), 1483-1493. 
713 Souza, D.C., Oyama, M.D. (2011). Climatic consequences of gradual desertification in the semi714 arid area of Northeast Brazil. Theoretical and Applied Climatology, 103, 345-357. climatological risk of desertification using the Köppen-Geiger classification and FAO aridity index. International Journal of Climatology, 35, 2210-2222.

Teutschbein, C., Seibert, J. (2012). Bias correction of regional climate model simulations for hydrological climate-change impact studies: review and evaluation of different methods. Journal of Hydrology, 456-457, 12-29. Geographical Society, 38(1), 55-94.

Van Vuuren, D.P., Edmonds, J., Kainuma, M., Riahi, K. et al. (2011). The representative concentration pathways: an overview. Climatic Change, 109, 5-31. methods for mapping of rainfall. Revista Brasileira de Engenharia Agrícola e Ambiental, 14, 970-978.

728

Watanabe, M., Suzuki, T., O’Ishi, R., Komuro, Y. et al. (2010). Improved climate simulations by MIROC5: mean states, variability, and climate sensitivity. Journal of Climate, 23, 6312-6335.

Zandonadi, L., Acquaotta, F., Fratianni, S., Zavattini, J.A. (2016). Changes in precipitation extremes in Brazil (Paraná River Basin). Theoretical and Applied Climatology, 123, 741-756.

Zhao, Q., Carr, F.H. (1997). A prognostic cloud scheme for operational NWP models. Monthly Weather Review, 125, 1931-1953. 
Table 1 Trends of the total precipitation and the average streamflow in each season of the year in the Xingó HPP drainage area in the period from 1975 to 2016. The values in bold are statistically significant at the $95 \%$ confidence based on the Mann-Kendall test

749

\begin{tabular}{|c|c|c|}
\hline & Precipitation $\left(\mathrm{mm} \cdot\right.$ year $\left.^{-1}\right)$ & Streamflow $\left(\mathrm{m}^{3} \cdot \mathrm{s}^{-1} \cdot\right.$ year $\left.^{-1}\right)$ \\
\hline Summer & -1.8 & $\mathbf{- 6 4 . 4}$ \\
\hline Autumn & +0.1 & $\mathbf{- 4 9 . 7}$ \\
\hline Winter & $\mathbf{- 0 . 2}$ & $\mathbf{- 2 3 . 2}$ \\
\hline Spring & -0.9 & $\mathbf{- 2 6 . 7}$ \\
\hline
\end{tabular}

750

751

752

753

754

755

756

757

758

759

760

761

762

763

764 Table 2 Projections of precipitation and streamflow trends over the $21_{\text {st }}$ century (2011 to 2100 ) according to RCP4.5 and RCP8.5 scenarios of the Eta-HadGEM2-ES (EH2) and Eta-MIROC5 (EM5) regional climate model runs at the Xingó HPP. The values in bold were considered statistically significant at the $95 \%$ confidence level by the Mann-Kendall test

\begin{tabular}{|c|c|c|}
\hline & Precipitation $\left(\mathrm{mm}\right.$. year $\left.^{-1}\right)$ & Streamflow $\left(\mathrm{m}^{3} \cdot \mathrm{s}^{-1} \cdot\right.$ year $\left.^{-1}\right)$ \\
\hline EH2 RCP4.5 & -0.7 & -4.6 \\
\hline EH2 RCP8.5 & $\mathbf{- 2 . 1}$ & $\mathbf{- 1 2 . 2}$ \\
\hline EM5 RCP4.5 & $\mathbf{- 1 . 2}$ & $\mathbf{- 9 . 3}$ \\
\hline EM5 RCP8.5 & $\mathbf{- 1 . 3}$ & $\mathbf{- 8 . 5}$ \\
\hline
\end{tabular}



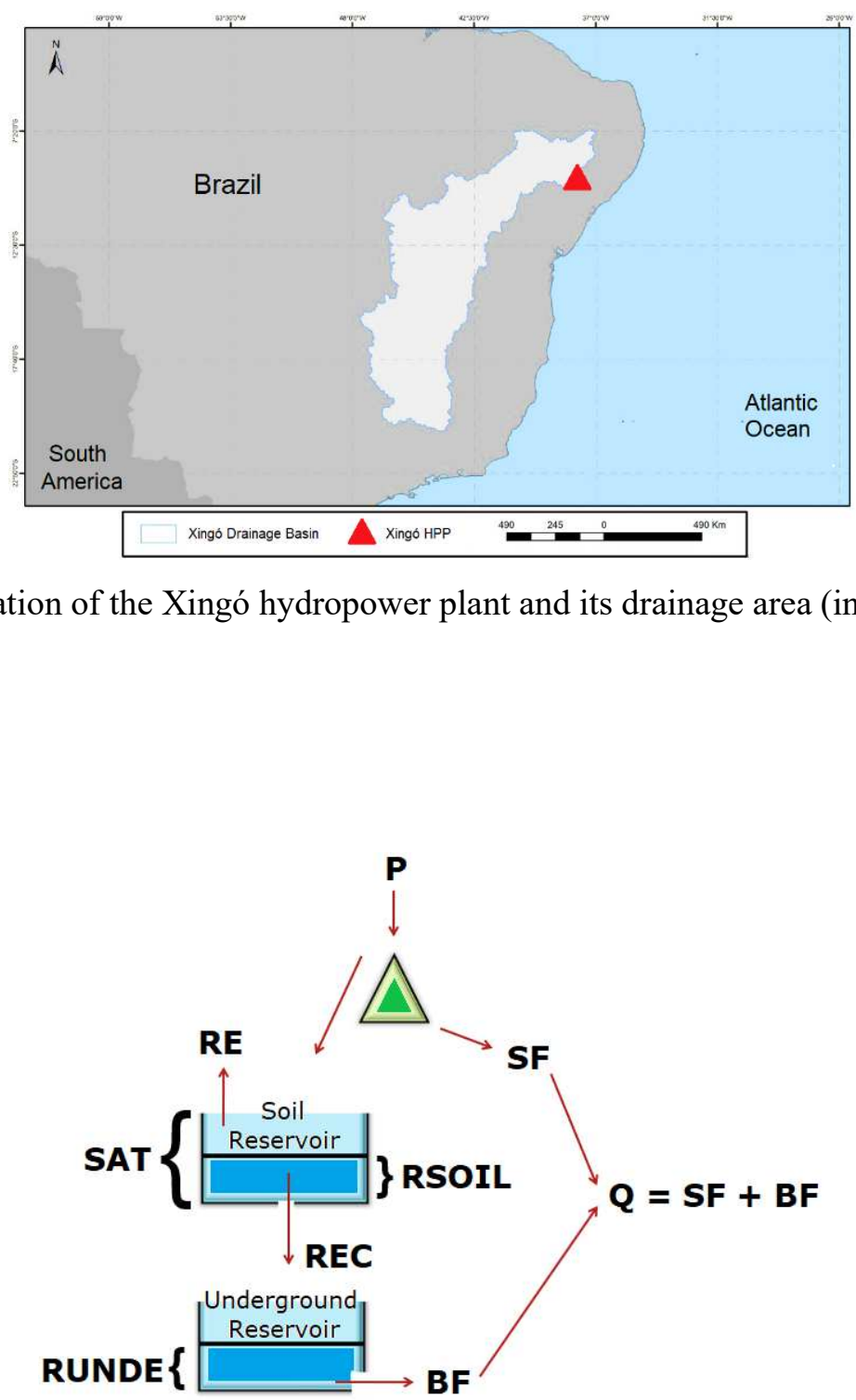

779 Fig. 2 SMAP hydrological model representation with monthly discretization (adapted from Lopes et al. 1982)

781

782 


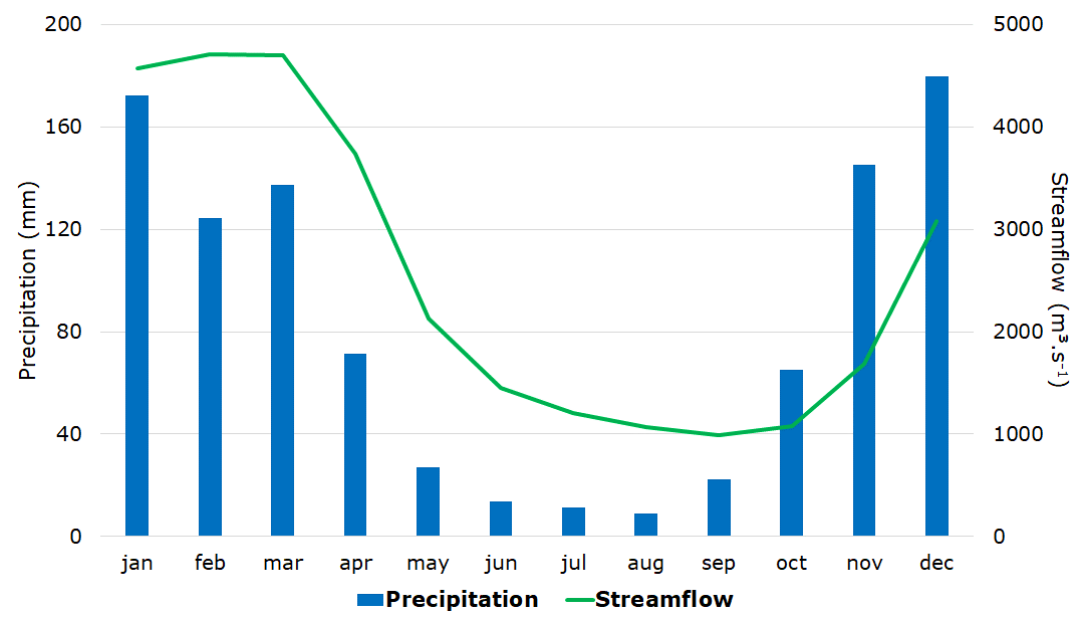

787 Fig. 3 Monthly long-term average of precipitation (mm, blue bars) and streamflow $\left(\mathrm{m}^{3} . \mathrm{s}^{-1}\right.$, green curve) in the Xingó HPP drainage basin for the period from 1975 to 2016

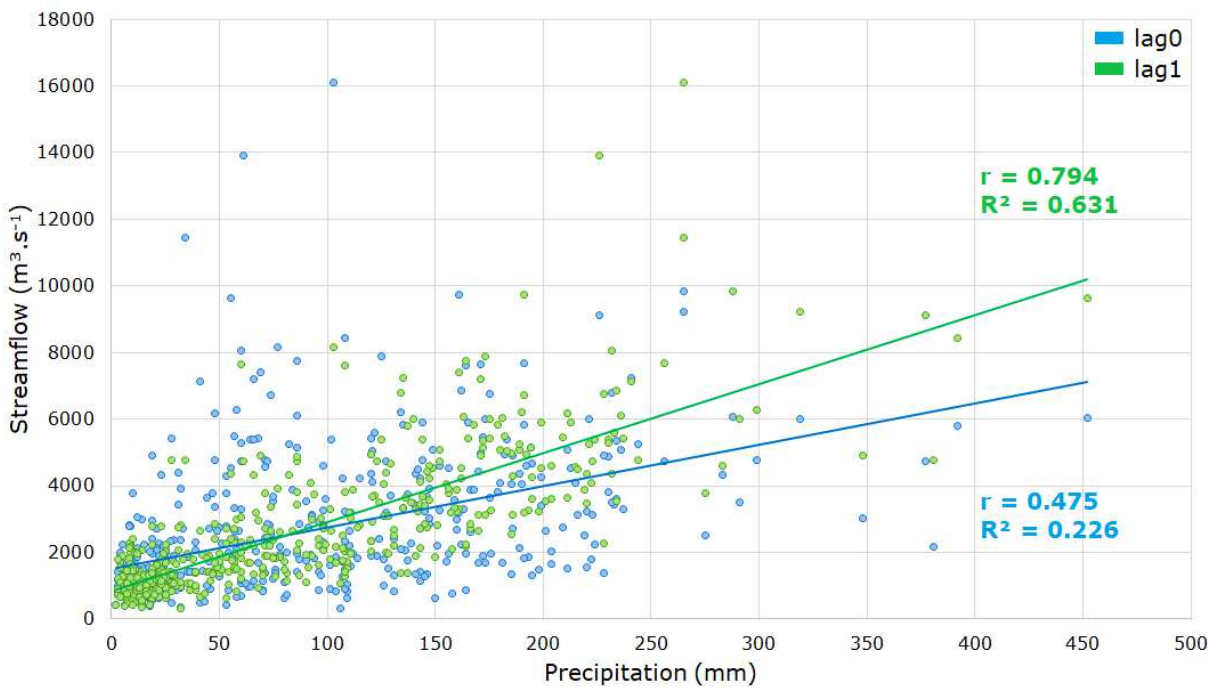

Fig. 4 Correlation between monthly precipitation $(\mathrm{mm})$ and monthly streamflow $\left(\mathrm{m}^{3} \cdot \mathrm{s}^{-1}\right)$ considering lag0 (rainfall and streamflow of the same month; in blue color) and lag1 (streamflow against rainfall of the previous month; in green color) in the Xingó HPP drainage area for the period from 1975 to 2016 . The correlation $(r)$ and determination $\left(\mathrm{R}^{2}\right)$ coefficients values are shown in the graph 


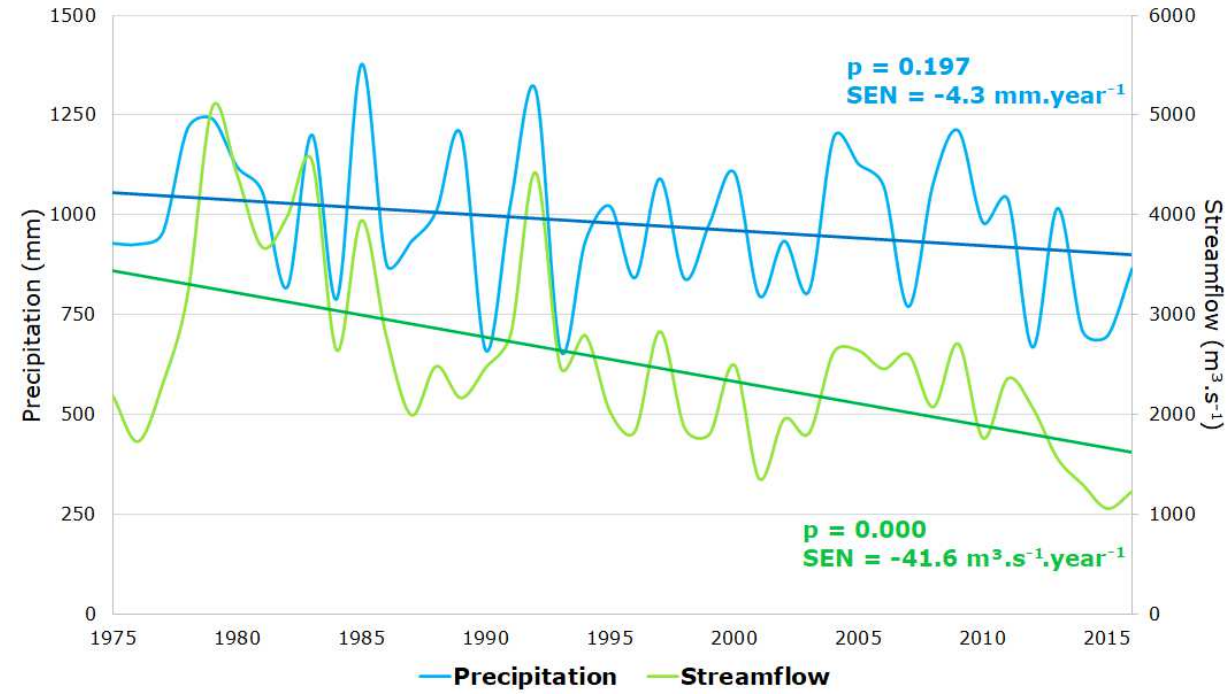

801 Fig. 5 Total annual rainfall ( $\mathrm{mm}$; in blue) and average annual streamflow $\left(\mathrm{m}^{3} \cdot \mathrm{s}^{-1}\right.$; in green) observed in the Xingó HPP drainage basin between 1975 and 2016. The trends significance (p) and magnitude (SEN) values obtained through statistical tests are shown

804

805

806

807

808

809

810
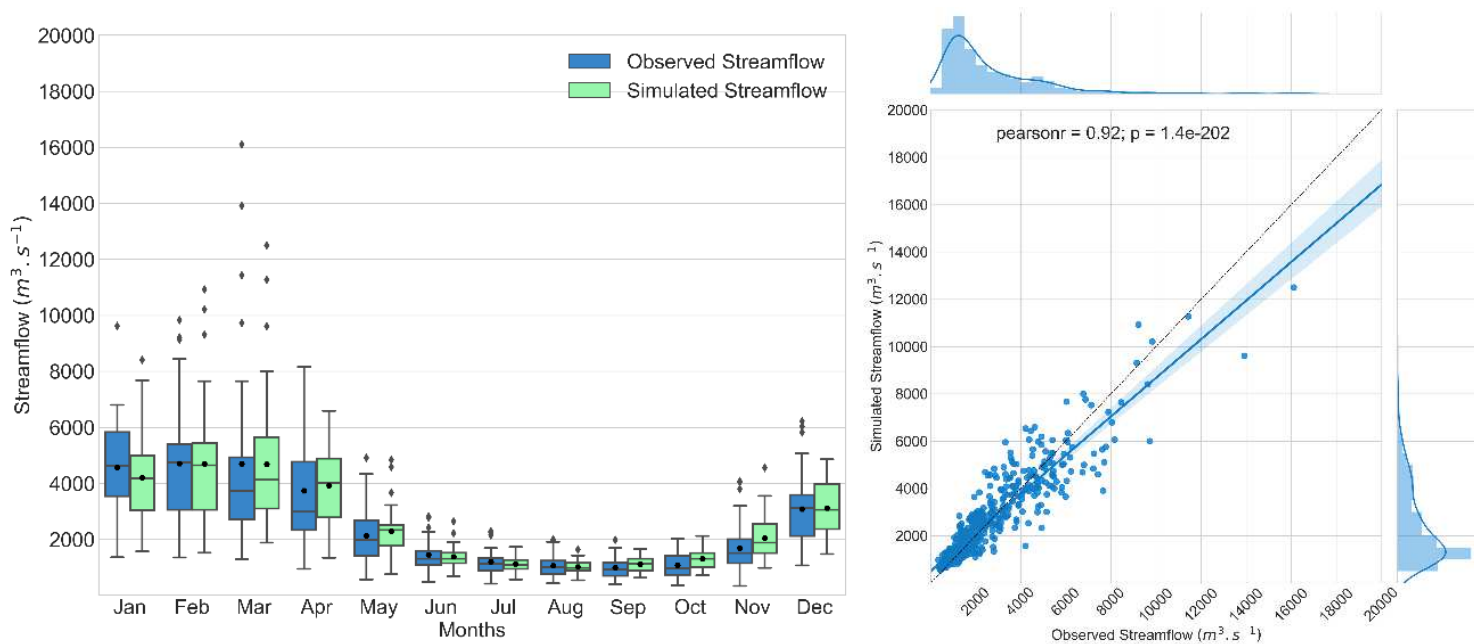

Fig. 6 Boxplots (left) and joint plots (right) of observed streamflow (ONS) and simulated streamflow $\left(\mathrm{m}^{3} \cdot \mathrm{s}^{-1}\right)$ from the SMAP hydrological model for the Xingó HPP for the period from 1975 to 2016 
Precipitation

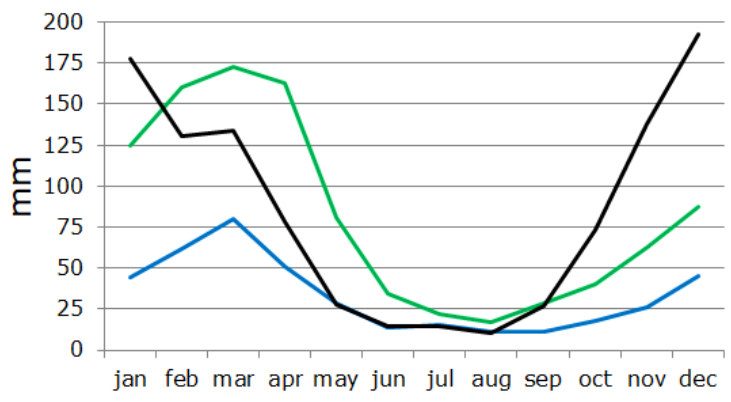

813

814

815

816

817

818

819
820

821

822

823

824

825
Temperature

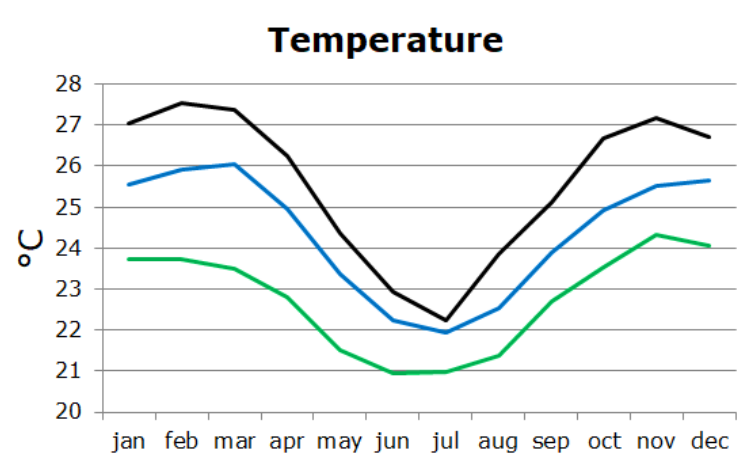

-Eta-HadGEM2-ES -Eta-MIROC5 - Observed

Fig. 7 Monthly long-term average of total precipitation ( $\mathrm{mm}$; left) and air temperature $\left({ }^{\circ} \mathrm{C}\right.$; right) observed and simulated by the Eta-HadGEM2-ES and Eta-MIROC5 climate model runs in the Xingó HPP drainage basin between 1975 and 1990 


\section{Annual Precipitation - Xingó}

828

829

830

831

832

833

834
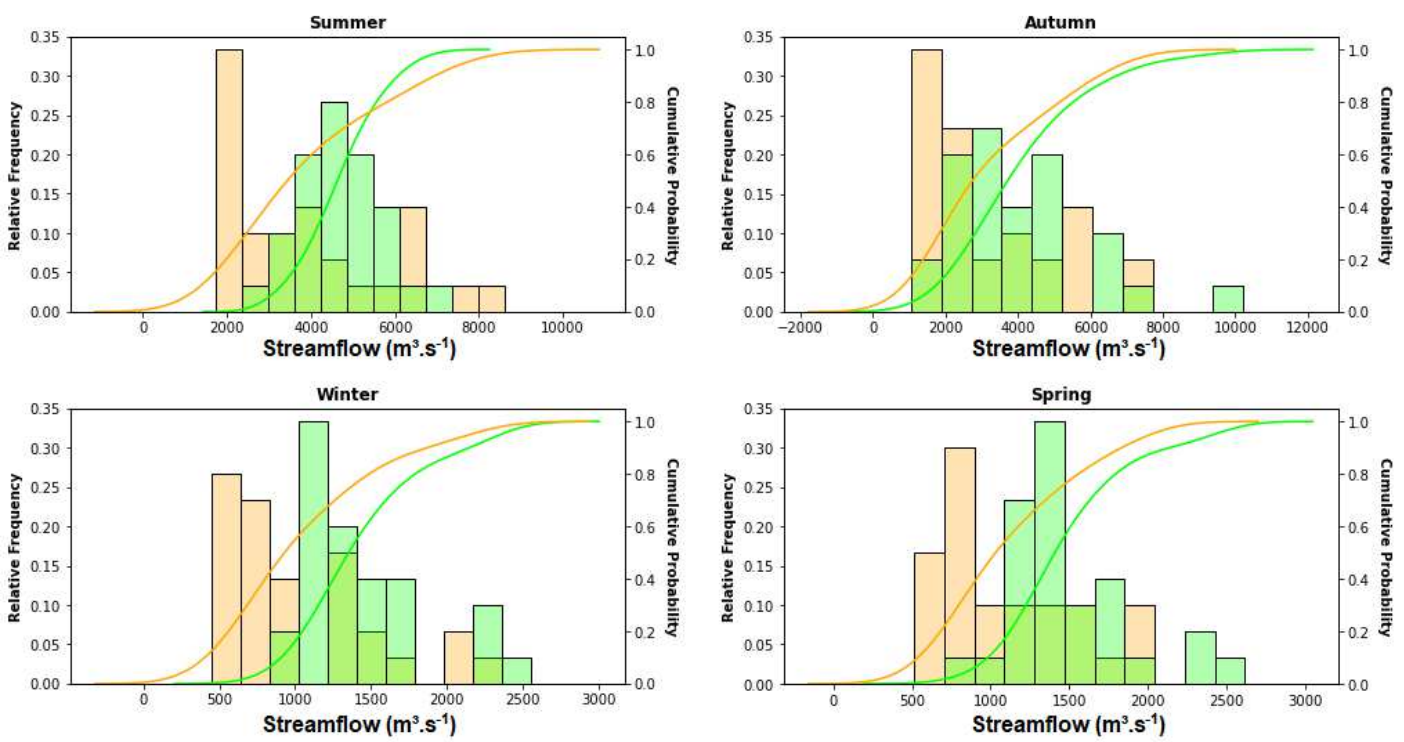

835

836

837

838

839

840

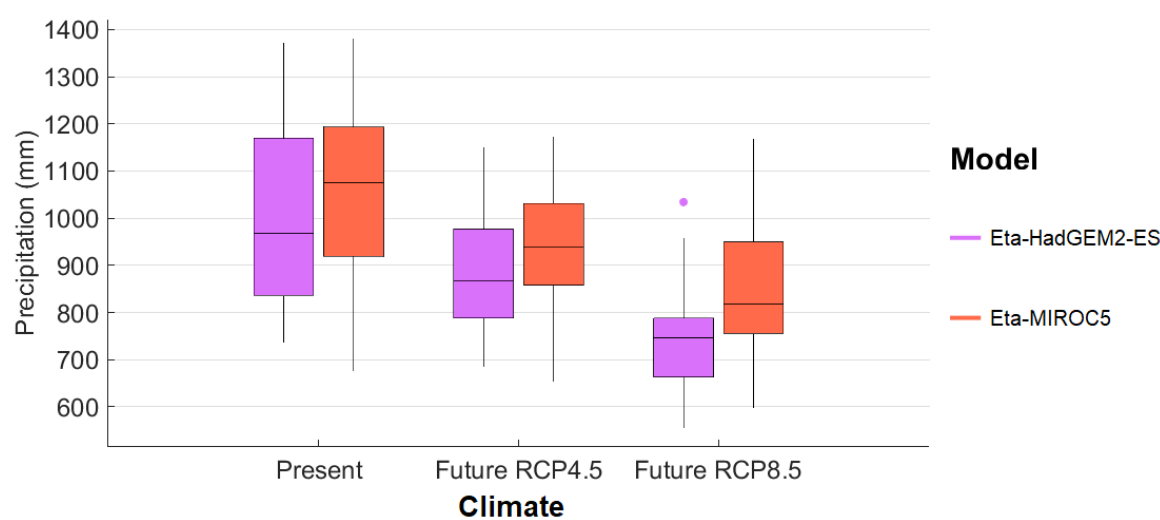

Fig. 9 Boxplots of annual rainfall volumes (mm) simulated in the present climate (1961 to 1990) and the future climate (2011 to 2100) by the Eta-HadGEM2-ES and Eta-MIROC5 regional climate model runs after the application of the monthly linear factor of bias correction considering the RCP4.5 and RCP8.5 IPCC scenarios in the Xingó HPP drainage area

- Present Climate

Future Climate

Fig. 10 Relative and cumulative distribution functions of mean seasonal streamflow $\left(\mathrm{m}^{3} \cdot \mathrm{s}^{-1}\right)$ observed in the present climate (1961 to 1990, in green color) and simulated by the SMAP hydrological model using data from the Eta-HadGEM2-ES and Eta-MIROC5 climate model runs in the future climate (2011 to 2100 , in orange color), after monthly bias correction, considering the RCP4.5 and RCP8.5 IPCC scenarios at Xingó HPP 
50

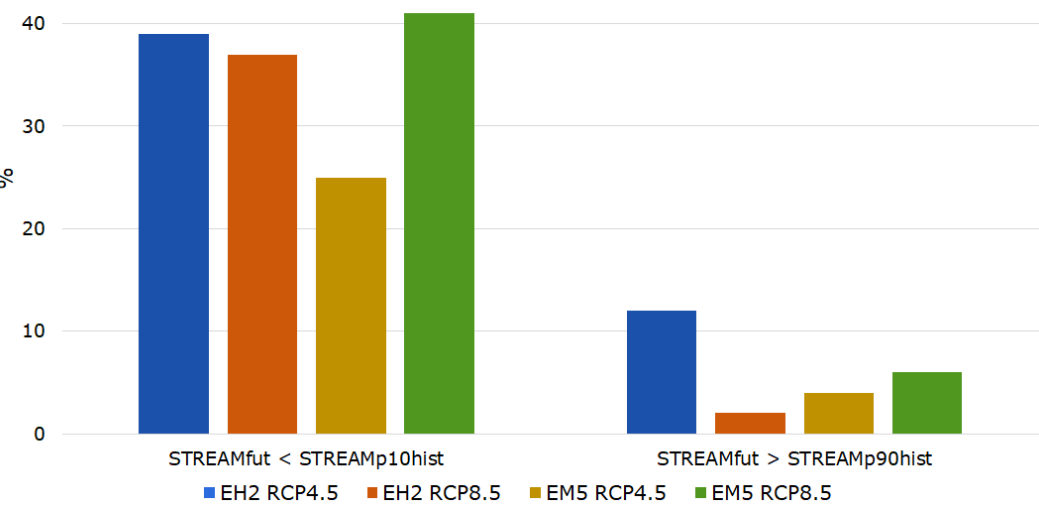

845 REAMfut < STREAMp10hist STREAMfut > STREAMP90hist

Fig. 11 Projections of the average annual streamflow percentage (STREAMfut) between 2011

847 and 2100 below the $10_{\text {th }}$ percentile (STREAMp10hist) of the historical period (1991 to 1990) and 848 above the $90^{\text {th }}$ percentile (STREAMp90hist), according to the RCP4.5 and RCP8.5 scenarios of 849 the Eta-HadGEM2-ES (EH2) and Eta-MIROC5 (EM5) models at Xingó HPP 
Figures

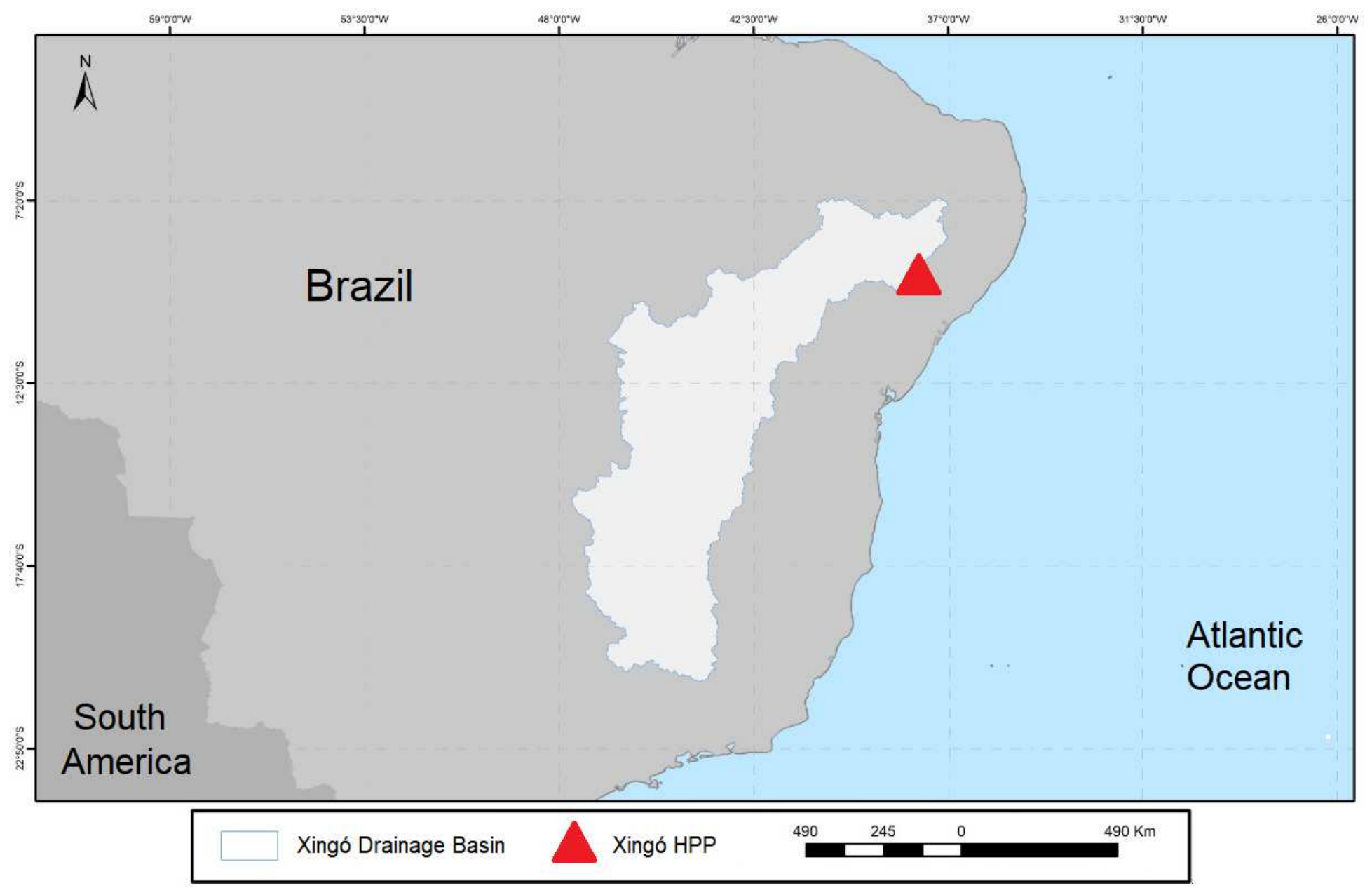

Figure 1

Location of the Xingó hydropower plant and its drainage area (in white color) 


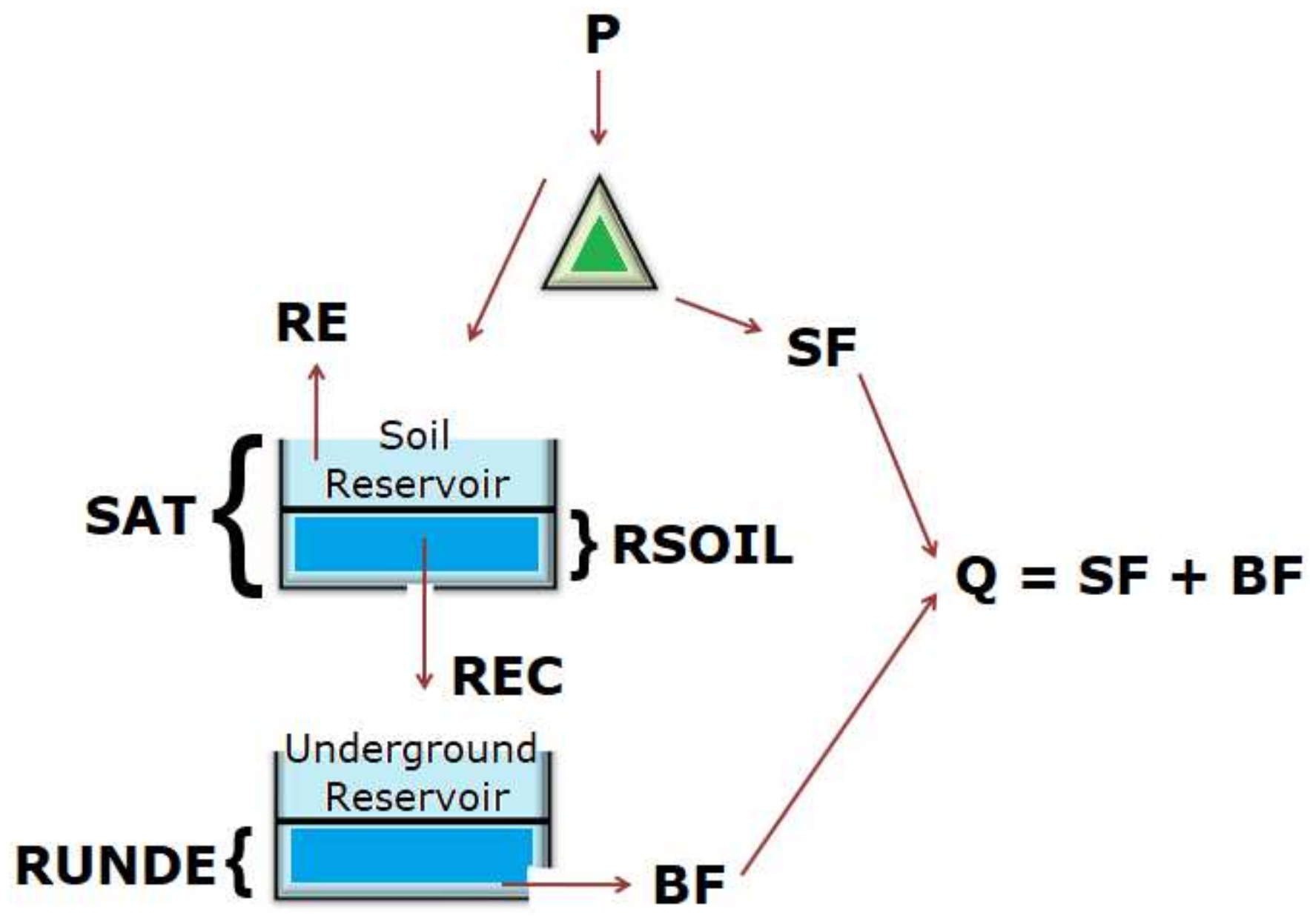

Figure 2

SMAP hydrological model representation with monthly discretization (adapted from Lopes et al. 1982) 


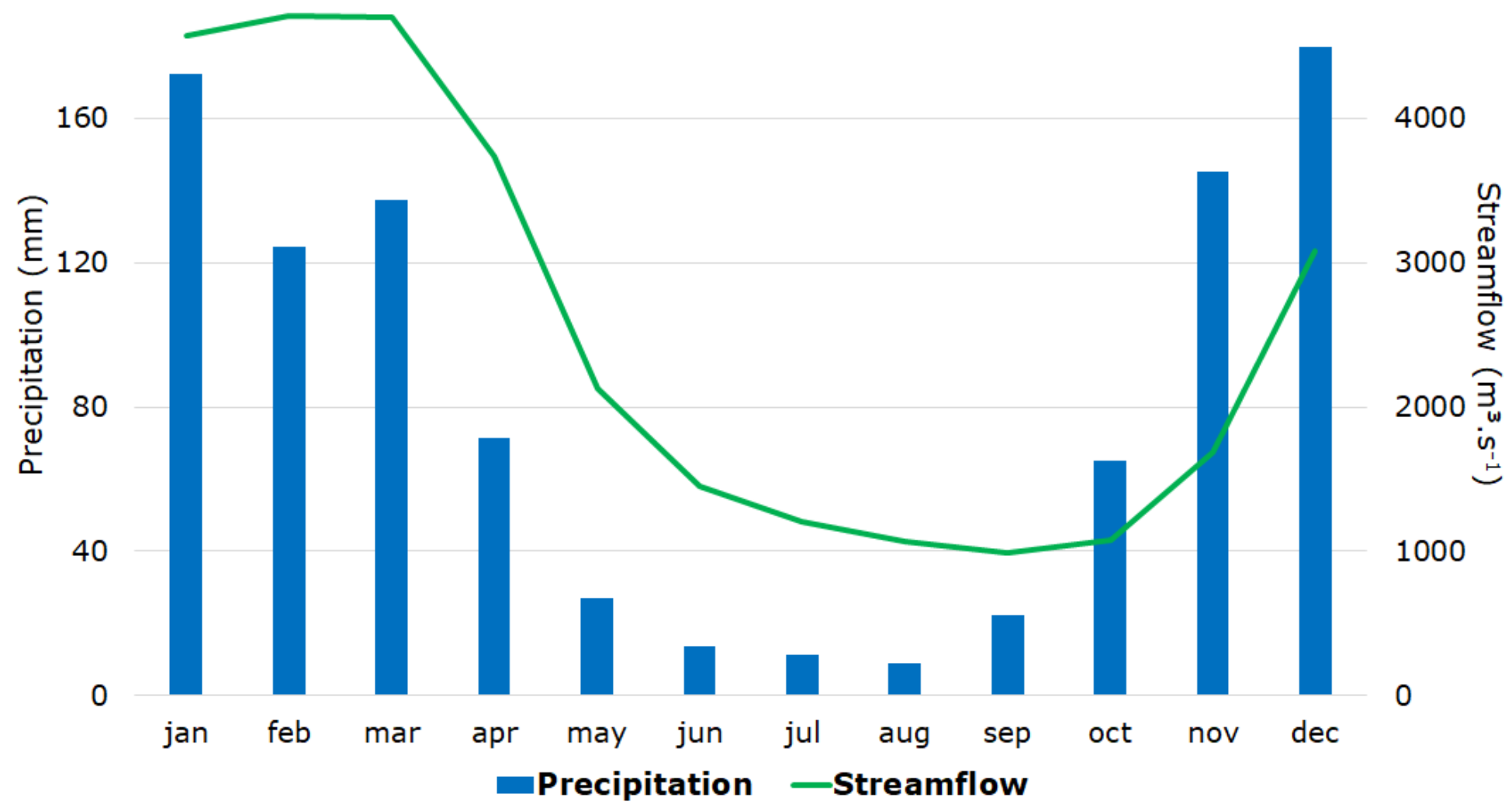

\section{Figure 3}

Monthly long-term average of precipitation ( $\mathrm{mm}$, blue bars) and streamflow ( $\mathrm{m}^{3} . \mathrm{s}-1$, green curve) in the Xingó HPP drainage basin for the period from 1975 to 2016

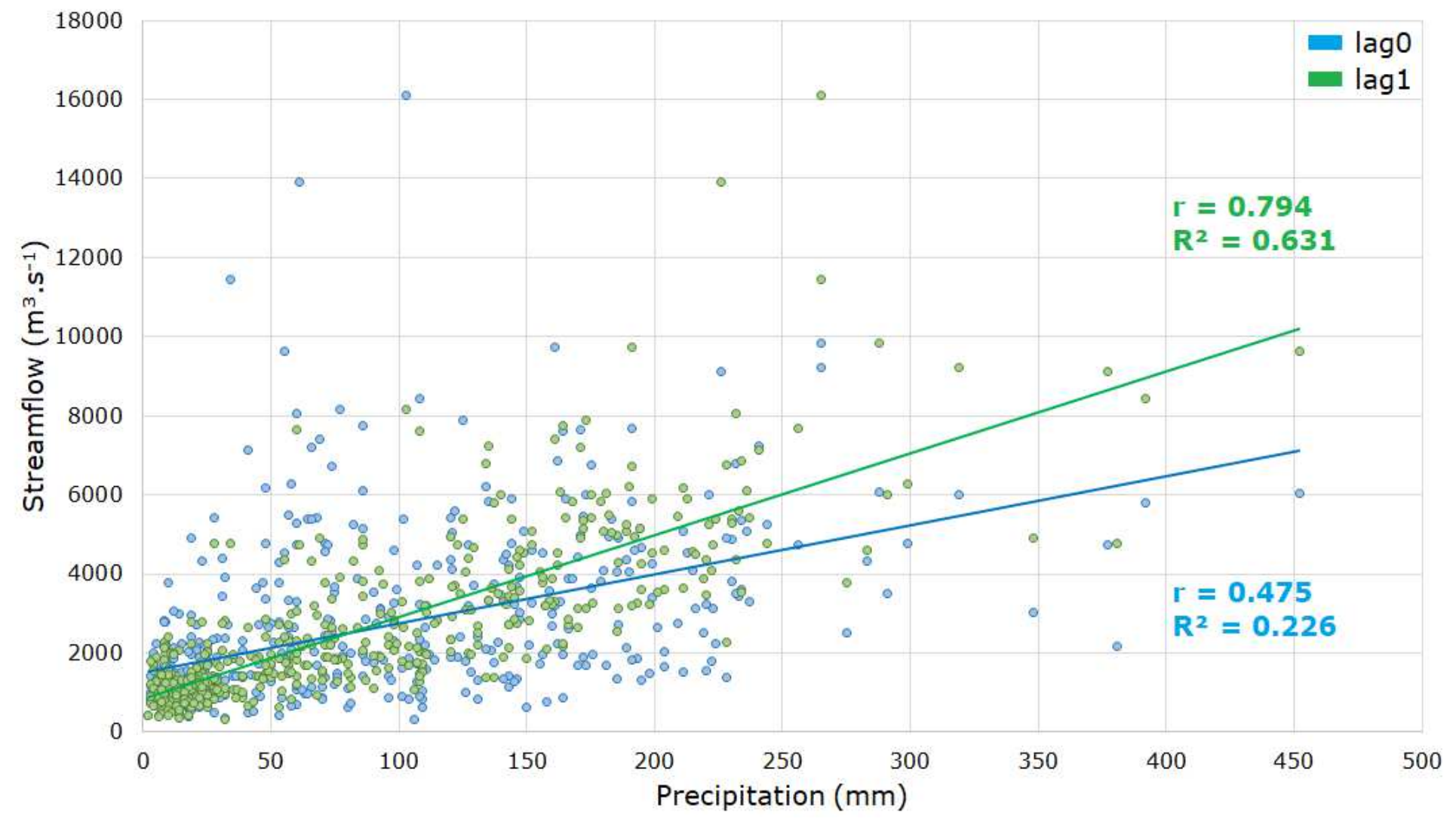


Figure 4

Correlation between monthly precipitation $(\mathrm{mm})$ and monthly streamflow $\left(\mathrm{m}^{3} . \mathrm{s}-1\right)$ considering lag0 (rainfall and streamflow of the same month; in blue color) and lag1 (streamflow against rainfall of the previous month; in green color) in the Xingó HPP drainage area for the period from 1975 to 2016. The correlation $(r)$ and determination $\left(\mathrm{R}^{2}\right)$ coefficients values are shown in the graph

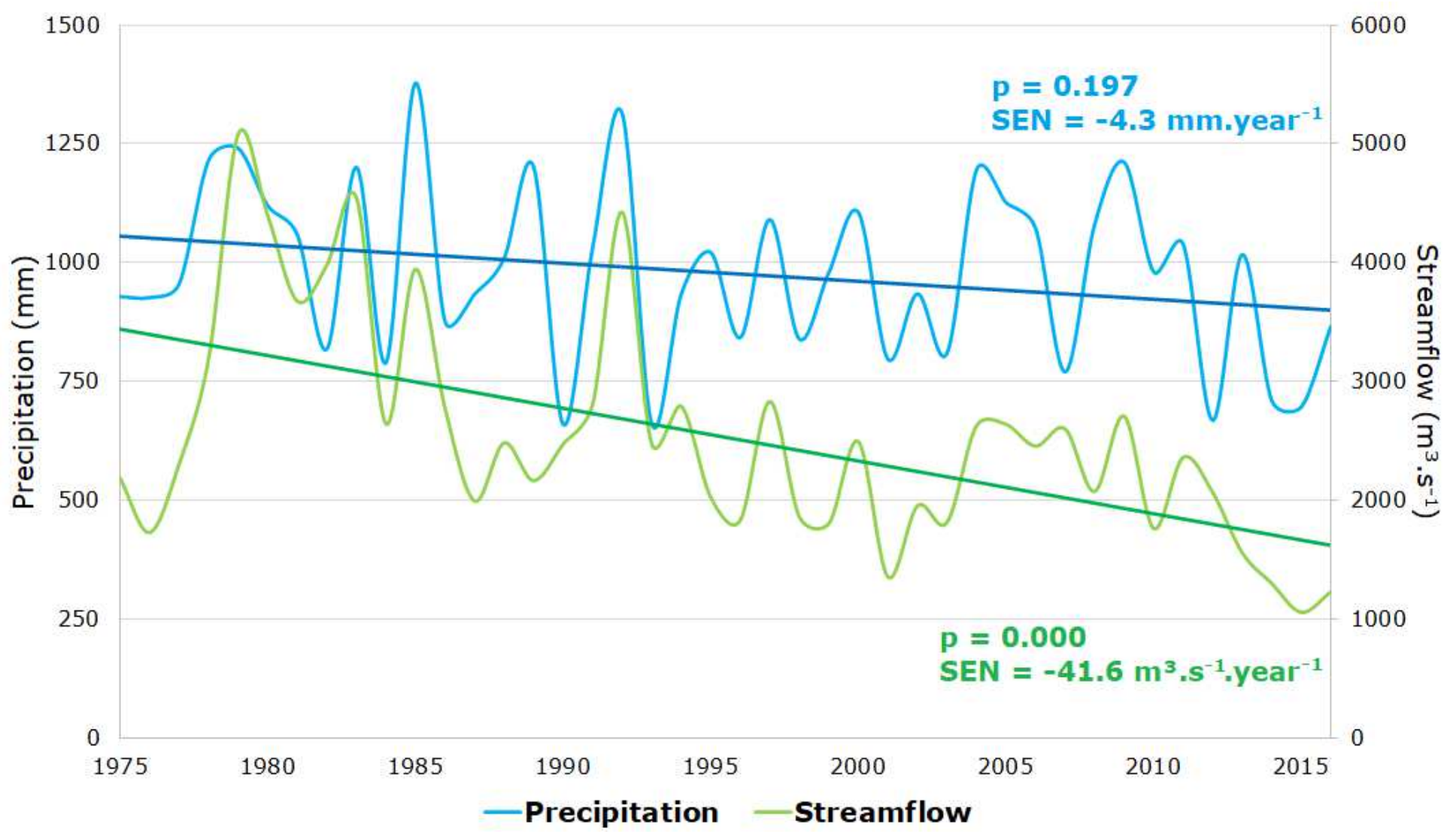

\section{Figure 5}

Total annual rainfall ( $\mathrm{mm}$; in blue) and average annual streamflow ( $\mathrm{m}^{3} . \mathrm{s}-1$; in green) observed in the Xingó HPP drainage basin between 1975 and 2016. The trends significance (p) and magnitude (SEN) values obtained through statistical tests are shown 

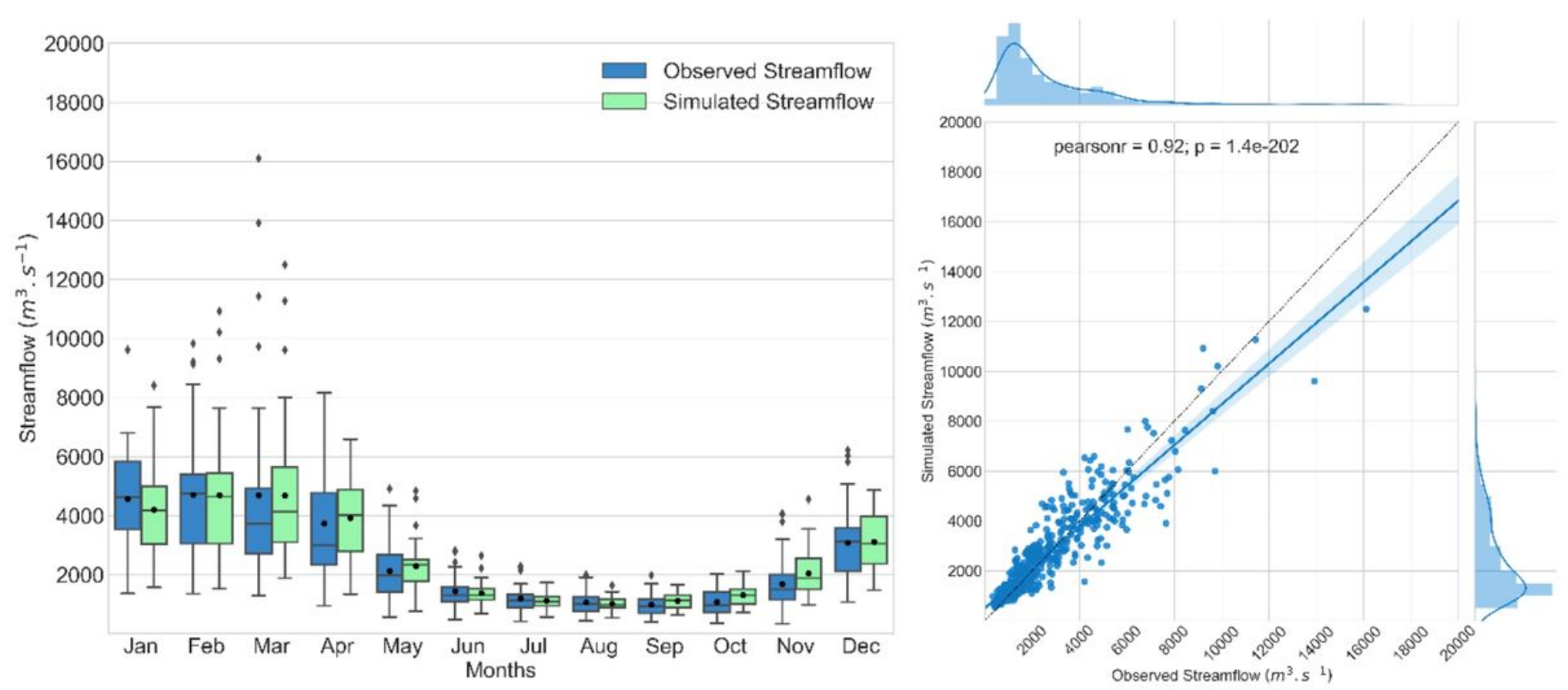

Figure 6

Boxplots (left) and joint plots (right) of observed streamflow (ONS) and simulated streamflow $\left(\mathrm{m}^{3} . \mathrm{s}-1\right)$ from the SMAP hydrological model for the Xingó HPP for the period from 1975 to 2016

\section{Precipitation}

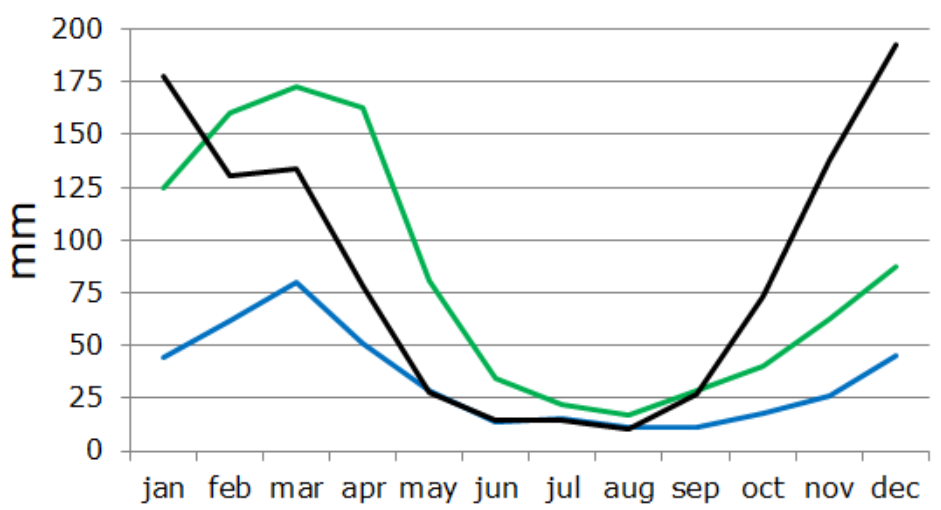

-Eta-HadGEM2-ES —Eta-MIROC5 — Observed

\section{Temperature}

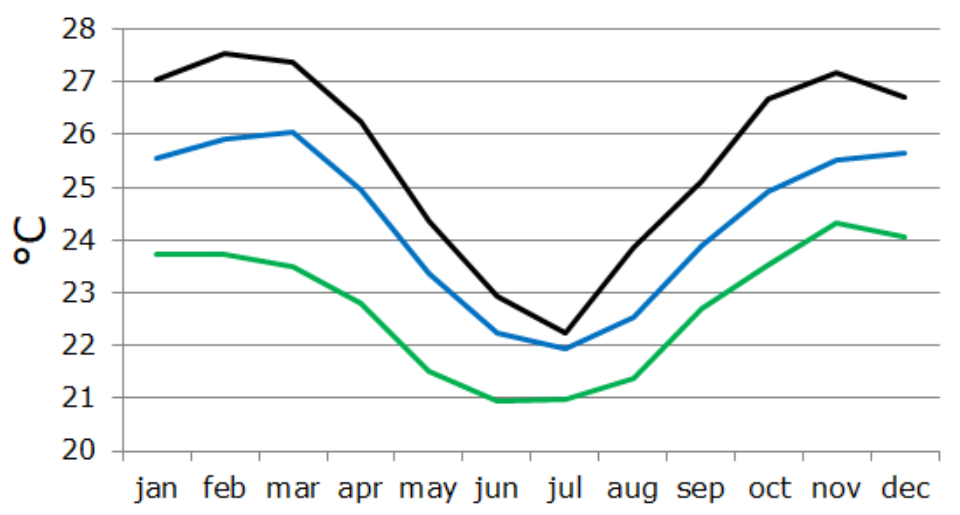

Figure 7

Monthly long-term average of total precipitation ( $\mathrm{mm}$; left) and air temperature $\left({ }^{\circ} \mathrm{C}\right.$; right) observed and simulated by the Eta-HadGEM2-ES and Eta-MIROC5 climate model runs in the Xingó HPP drainage basin between 1975 and 1990 

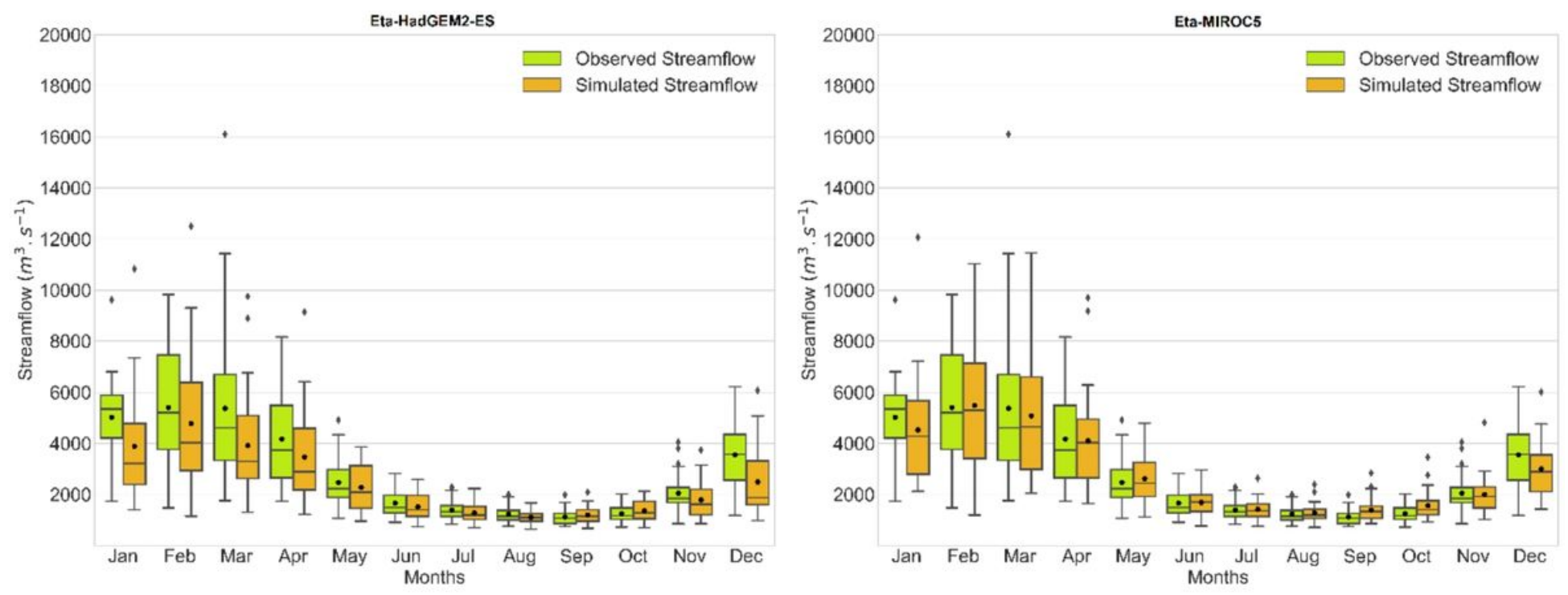

Figure 8

Streamflow ( $\left.\mathrm{m}^{3} . \mathrm{s}-1\right)$ simulated by SMAP hydrological model driven by the Eta-HadGEM2-ES (left) and the Eta-MIROC5 (right) climate model data after bias correction at Xingó HPP between 1975 and 1990

\section{Annual Precipitation - Xingó}

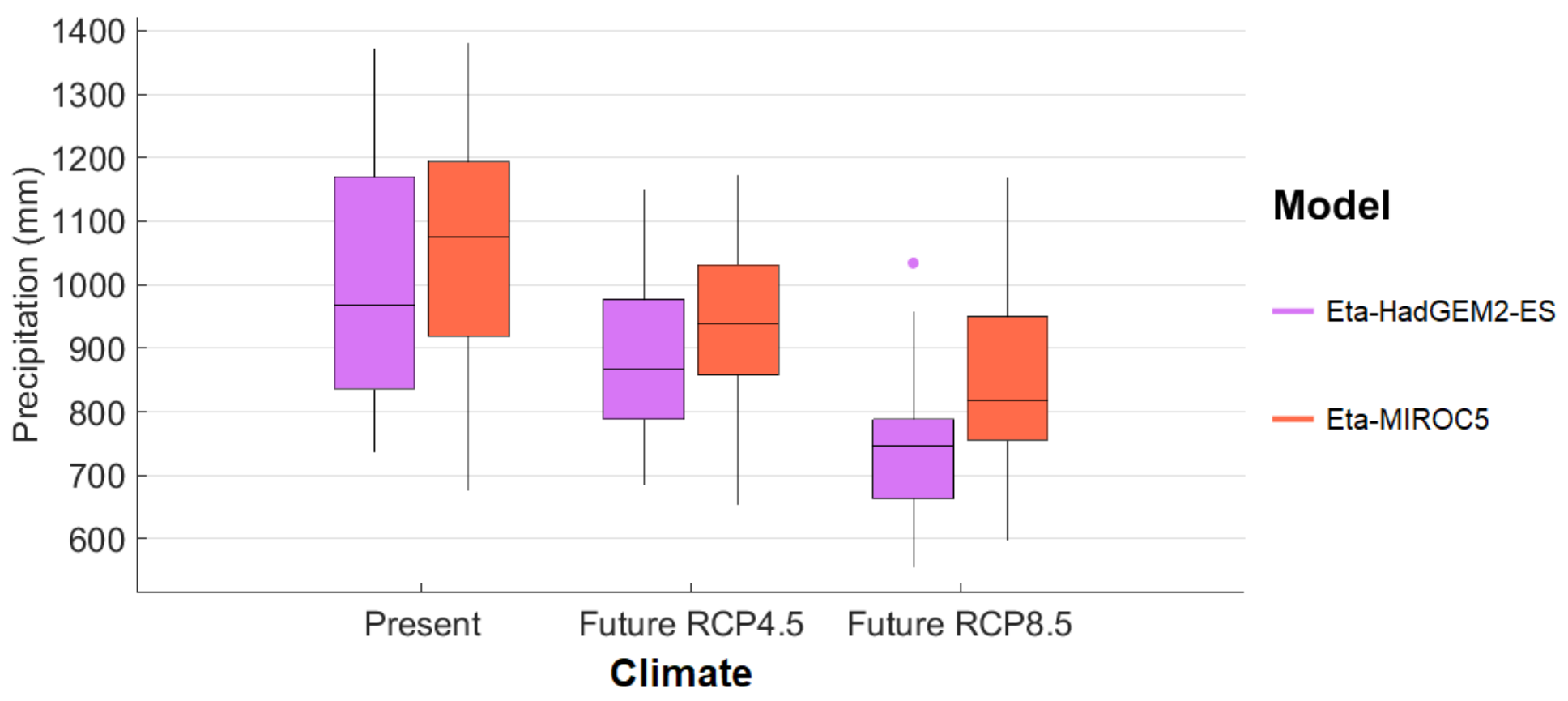

Figure 9

Boxplots of annual rainfall volumes (mm) simulated in the present climate (1961 to 1990) and the future climate (2011 to 2100) by the Eta-HadGEM2-ES and Eta-MIROC5 regional climate model runs after the application of the monthly linear factor of bias correction considering the RCP4.5 and RCP8.5 IPCC scenarios in the Xingó HPP drainage area 

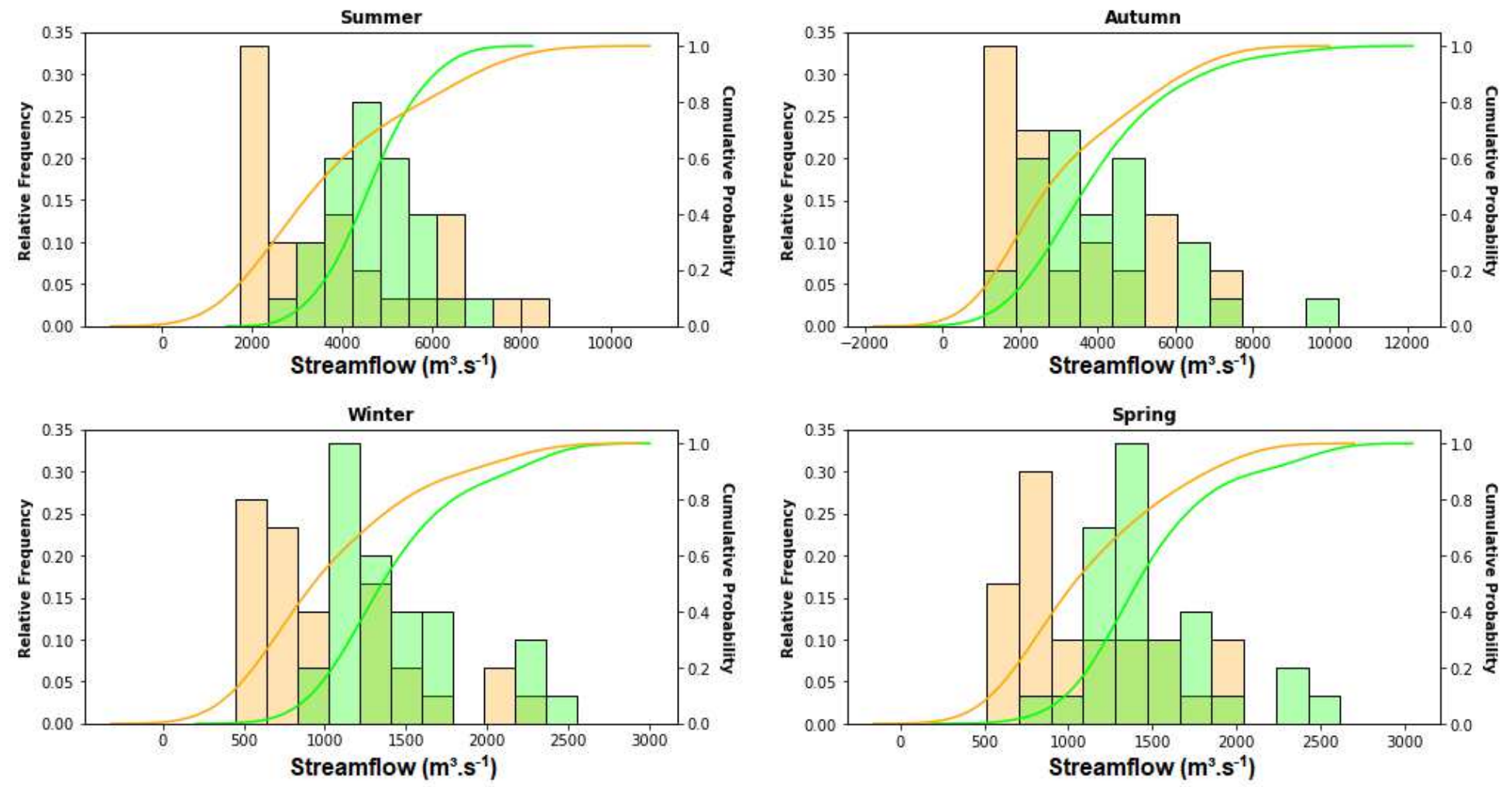

- Present Climate

Future Climate

Figure 10

Relative and cumulative distribution functions of mean seasonal streamflow $\left(\mathrm{m}^{3} . \mathrm{s}-1\right)$ observed in the present climate (1961 to 1990, in green color) and simulated by the SMAP hydrological model using data from the Eta-HadGEM2-ES and Eta-MIROC5 climate model runs in the future climate (2011 to 2100, in orange color), after monthly bias correction, considering the RCP4.5 and RCP8.5 IPCC scenarios at Xingó HPP 


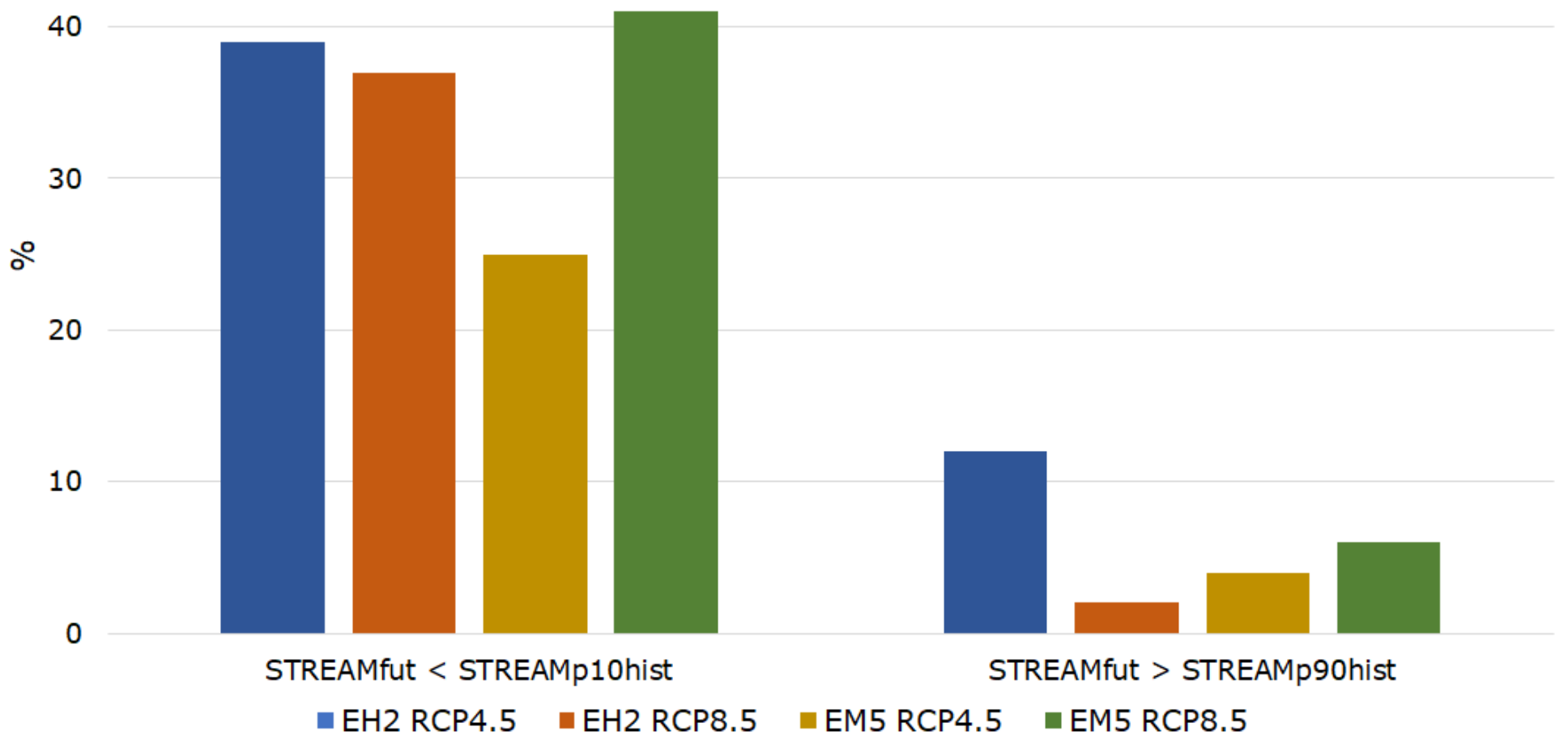

\section{Figure 11}

Projections of the average annual streamflow percentage (STREAMfut) between 2011 and 2100 below the 10th percentile (STREAMp10hist) of the historical period (1991 to 1990) and above the 90th percentile (STREAMp90hist), according to the RCP4.5 and RCP8.5 scenarios of the Eta-HadGEM2-ES (EH2) and Eta-MIROC5 (EM5) models at Xingó HPP

\section{Supplementary Files}

This is a list of supplementary files associated with this preprint. Click to download.

- CoverLetter.pdf 